\title{
Equilibrium slopes and cross-shore velocity asymmetries in a storm-dominated, barred nearshore system
}

\author{
Brian Greenwood and Philip D. Osborne \\ Scarborough College Coastal Research Group, University of Toronto, 1265 Military Trail, Scarborough, Ont., \\ MIC 1A4, Canada
}

(Received September 29, 1989; revision accepted May 16, 1990)

\section{ABSTRACT}

Greenwood, B. and Osborne, P.D., 1991. Equilibrium slopes and cross-shore velocity asymmetries in a storm-dominated, barred nearshore system. Mar. Geol., 96: 211-235.

The near-bed ( $0.10 \mathrm{~m}$ elevation), horizontal velocities were measured across a two-barred, lacustrine shoreface during a storm and reveal a spatially coherent but temporally variable pattern in the low-order moments of the velocity field. Large cross-shore velocity asymmetries indicated:

(1) Spatially extensive and temporally persistent offshore mean flows (up to $0.18 \mathrm{~m} \mathrm{~s}^{-1}$ across the landward slope of the linear outer bar) reflecting an undertow driven by a wave-induced setup.

(2) An onshore directed skewness opposing the mean flow, of wind wave origin and persistent under propagating bores in the inner bar system long after this asymmetry had disappeared from the outer bar.

Extensive sediment reactivation with near-zero net sediment flux over the whole of the upper shoreface indicated a sediment prism in a steady state (volumetrically) over the storm cycle. Uniform depths of sediment reactivation with zero bed elevation change over the storm cycle revealed local slopes in a steady state in the outer linear bar. However, time integration of the nearbed velocity field at this location indicated an offshore net flux of water, while sedimentary structures indicated bedform migration (and thus at least bedload) almost uniformly onshore when ripples and megaripples were present. The sediment transport giving rise to the local equilibrium cannot be explained therefore on the basis of the mean properties of the near-bed velocity vector, but requires knowledge of the time-varying, instantaneous sediment transport vector.

Onshore migration of the inner bar correlated well with the large and persistent onshore skewness of the velocity distribution in the inner surf zone associated with translatory surf bores throughout the storm decay period. Low-frequency oscillations were only significant close to the shoreline, but may have influenced the development of a sinuous three-dimensional inner bar form as it migrated onshore.

\section{Introduction}

The upper shoreface of sandy, storm-wave dominated coastlines often exhibits an "equilibrium morphology" characterized by the presence of one or more bars (Zenkovitch, 1967; Hands, 1976; Greenwood and Davidson-Arnott, 1979; Greenwood, 1982). Under a "steady equilibrium" the time-averaged total sediment transport rate approaches zero at every point on the surface. Greenwood (1987) suggested that bars may grow in amplitude with little change in form, existing as a "dynamic equilibrium" operating over several storms in a nearshore sand prism in "steady state". In contrast, a shoreface experiencing considerable swell may evolve from non-barred (planar) to barred and back to non-barred through a cyclic response to changing wave climate (Short, 1978, 1979; Wright et al., 1979; Sunamura, 1988). Although a large body of literature exists on the morphology, sedimentology and morphodynamics of barred slopes (e.g., Davidson-Arnott and Greenwood, 1974, 1976; Exon, 1975; Greenwood and Davidson-Arnott 1975, 1979; Carter, 1978; Hunter et al., 1979; Wright et al., 1979, 1986; Davidson-Arnott and Pember, 1980; Greenwood 
and Hale, 1980, 1982; Goldsmith et al. 1982; Bowman and Goldsmith. 1983; Wright and Short. 1983, 1984: Sallenger et al. 1985: Greenwood, 1987; Aagaard, 1988a, b, c). the sediment transport processes that develop and maintain barred slopes are still ill defined.

Theoretical expressions for equilibrium nearshore slopes derived from Bagnold's (1963, 1966) sediment transport equations (Inman and Bagnold, 1963; Inman and Frautschy 1966; Bowen, 1980a, b; Bailard, 1981; Bailard and Inman, 1981: Jago and Hardisty, 1984; Leontev, 1985) have been the most successful in predicting. at least qualitatively, observed slope behaviour. Bowen (1980a), for example, suggests that an "equilibrium" slope represents a surface over which fluid stresses are balanced by gravity through local variations in that slope. Stress induced by oscillatory currents associated with the incident waves provide a first-order transport mechanism, which can then be perturbed by other mechanisms to effect variation in slopes. These perturbations are manifested as odd moments of the velocity field, especially the mean and skewness. Since the major characteristics of barred topographies are local slope reversals, then (following Bowen's argument) mechanisms inducing local net sediment transport reversals must be explained. Reversals in the crossshore sediment transport vector (excluding the special case of rip currents) have been attributed to incident-wave induced asymmetries in the local velocity field (Inman and Frautschy, 1966; Wells, 1967; Bowen. 1980b; Bailard. 1981. 1983, 1987; Greenwood and Sherman, 1984: Trowbridge and Madsen, 1984; Hardisty, 1985; Doering, 1988; Doering and Bowen, 1989), infragravity wave drift velocities (Bowen and Inman, 1971; Bowen. 1980a; Holman and Bowen, 1982; Kim and Wright, 1987), long waves forced by wave groups (Larsen, 1982; Shi and Larsen, 1984; Doering and Bowen, 1989) and undertow resulting from gradients in wave setup (Longuet-Higgins and Stewart, 1964; Longuet-Higgins, 1983; Svendsen, 1984; Stive and Battjes, 1984; Leont'ev, 1985; Stive, 1986; Stive and Wind, 1986). Several theoretical expressions for cross-shore transport equilibrium depend upon bedload moving onshore and suspended load moving offshore (see Bowen, 1980a: Chappell,
1981; Leontev, 1985 for examplest. Recently. Roelvink and Stive (1989) used a modified Bailard (1981) total load sediment transport syuation. including a transport component contributed by turbulence which penetrates to the bed from the breaking surface wave, to model the spatially varying cross-shore sediment transport. The contributions to the depth-integrated velocity field (necessary in the Bailard formulation) were predicted for: (a) the breaking wave-induced turbulent flow, (b) incident wave-induced asymmetric oscillatory flow, (c) momentum decay-induced undertow, and (d) wave group-induced long wave flow. A series of laboratory tests showed qualitative agreement between the model and the observed development of a nearshore bar. It was further shown that the contributors to the transport were of the same order of magnitude with the exception of undertow, which dominated in the zone of maximum energy dissipation (wave breaking). At present, however. a theory of wave breaking and a formal description of breaker dynamics is lacking (see Longuet-Higgins, 1981; Basco, 1982); it is therefore questionable practice to develop and test sediment transport models for the upper shoreface with existing hydrodynamic theory.

Laboratory observations of reversals in net cross-shore sediment transport are extensive and a large number of quasi-theoretical expressions for predicting the direction and rate of cross-shore transport have been developed, based upon simple time-averaged wave and beach parameters. In general these do not predict local slope variations. and in any case they have been singularly unsuccessful in prototype applications (see Seymour and King, 1982 and Seymour and Castel. 1989 for a valuable review).

Field measurements of the hydrodynamics associated with barred profiles already exist (e.g. Wright et al., 1979, 1982, 1986, 1987; Huntley, 1980; Greenwood and Sherman, 1983, 1984. 1986a; Wright and Short, 1983; Greenwood and Mittler, 1984; Katoh, 1984; Sallenger et al., 1985; Greenwood and Osborne, 1990; Davidson-Arnott and McDonald, 1989). However, emphasis has been placed upon correlating large-scale morphological behaviour with incident wave character- 
istics (e.g., Sunamura and Takeda, 1984; Wright and Short, 1984; Wright et al., 1987) and infragravity wave characteristics (especially edge waves - e.g., Chappell and Wright, 1979; Sallenger and Holman, 1987; Bauer and Greenwood, 1990). To date, few studies have examined the near-bed velocity field and the direct response of the local sediment-water interface. Bailard (1983) shows a correlation between on-offshore sand transport across a tidal beach foreshore and spatial averages of the odd moments of the velocity field, when the latter were expressed as a function of wave height and sediment fall velocity; in this instance the beach remained essentially subplanar. Greenwood and Mittler (1984) show that the seaward slope angle of a large marine bar in steady state can be predicted by using the measured asymmetries (simple differences) in the on-offshore maximum orbital velocities and the formula of Inman and Frautschy (1966 - based on Bagnold's energetics concept). Greenwood and Sherman (1984) document local scour and accretion pattern which correlate with spatial gradients in both the timeaveraged mean and skewness of the cross-shore velocity field (see also Hardisty, 1985). Observed decreases in both the offshore mean flow and velocity skewness from bar trough to crest provided some support for Leont'ev's (1985) model for equilibrium bar-trough topography. In this study there was little evidence for the existence of low-frequency waves which might have induced these asymmetries. Sallenger et al. (1985) document the offshore migration of a nearshore bar under breaking waves and suggest a possible correlation with measured offshore mean flows up to $0.50 \mathrm{~m} \mathrm{~s}^{-1}$; however, little evidence was found to support a relationship with infragravity waves (Sallenger and Holman, 1987). In contrast to these two studies, Bauer and Greenwood (1990) establish a strong correlation between erosion, accretion and morphological adjustment of an outer linear bar and theoretical drift velocities for a high mode, standing edge wave; the edge wave was identified from detailed measurements of the cross-shore and alongshore wave structure.

Conclusive field evidence for net sediment transport reversals over barred topographies, together with the contemporaneous fluid dynamics are limited. Structural signatures left by migrating bedforms do confirm transport reversals at least for sediment generally interpreted as bedload (e.g. Greenwood and Davidson-Arnott, 1975, 1979 ; Greenwood and Hale, 1980, 1982; Greenwood and Mittler, 1984; Short 1984). The angle-of-repose bedding identified also indicates the presence of separation vortices and hence extensive sediment suspension. At present considerable debate exists concerning the relative contributions of suspension and bedload to the total transport (Komar, 1978; Hanes, 1988; Sternberg et al., 1989: Zampol and Inman, 1989) as well as the direction of any net transports of these two components under complex surf zone flows and bed configurations.

The net cross-shore transport vector in the prototype will be constrained by interactions of a number of mechanisms (Kobayashi, 1988): mass transport velocities from incident and secondary waves (e.g., Longuet-Higgins, 1953; Bowen and Inman, 1971; Carter et al., 1973; Holman and Bowen, 1982; Bowen and Huntley, 1984), wave shape asymmetry (e.g., Inman and Bagnold. 1963; Wells, 1967: Doering and Bowen, 1985, 1989), rip currents (e.g., Shepard et al., 1941; Cook, 1970; Sonu, 1972; Greenwood and Davidson-Arnott, 1979; Short, 1985; Bowman et al., 1988a,b), undertow (e.g., Dhyr-Nielsen and Sorensen, 1970; Longuet Higgins, 1983; Svendsen, 1984; Dally and Dean, 1984; Stive and Battjes, 1984; Leont'ev. 1985), cross-shore variation in the longshore current (e.g., Longuet-Higgins, 1972; Bailard, 1981; Deigaard et al., 1986), and the configuration of the bottom boundary (e.g., Inman and Bowen, 1963; Sleath, 1984) as well as the downslope component of gravity induced by the slope itself (Inman and Bagnold, 1963; Bowen, 1980a,b; Bailard, 1981). The roles of these mechanisms have yet to be fully evaluated, but it is clear that such interactions will be expressed in the time-varying near-bed velocity. Furthermore, the moments of the velocity distribution provide a first approximation to the potential for sediment transport (Bowen, 1980a,b; Bailard, 1981; Guza and Thornton, 1985; Bowen and Doering, 1985) and the direction of this transport will be constrained by values of the odd moments (mean and skewness). There is need therefore, for a fuller understanding of the links between 
beach slope and the magnitudes and distributions of the near-bed velocity moments (Bailard. 1987), especially under active sediment transport conditions with an equilibrium morphology.

In this paper field measurements are presented of the near-bed fluid velocities, the associated timeaveraged sediment flux and the resulting morphodynamics of a barred nearshore slope during high wave conditions. A steady state morphology and balanced sediment transport condition is illustrated and the low-order moments of the cross-shor velocity field are examined for their potential role in the sediment transport controlling this steady state. Possible forcing mechanisms for the cross-shore velocities observed are also considered briefly.

\section{Location of study}

The study site, located at Wymbolwood Beach, Ontario, Canada (Fig.1), consisted of two near-

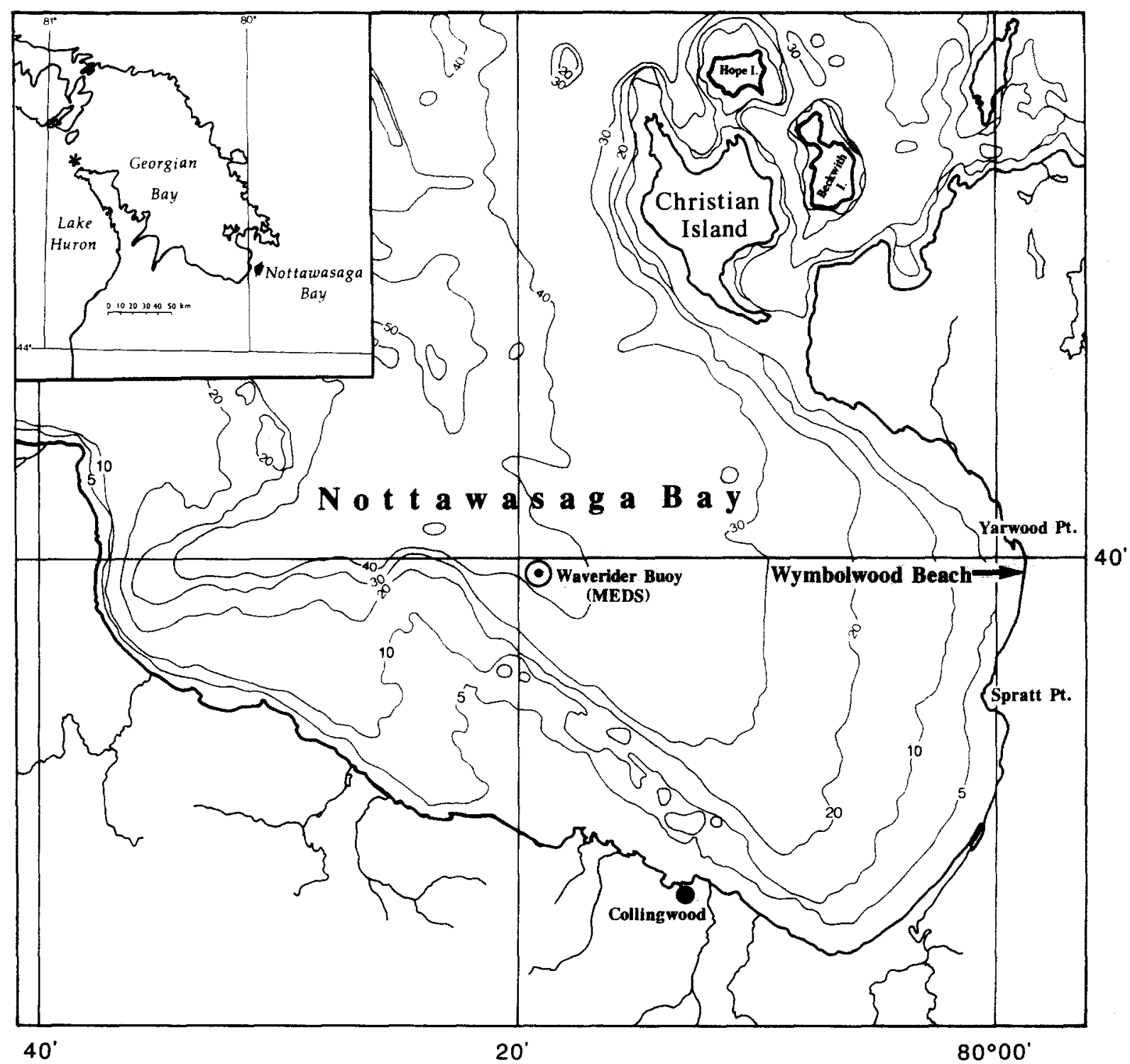

Fig.1. Location of Wymbolwood Beach study site. The asterisk in the inset marks the location of the meteorological station which existed on Cove Island; the location of a wave rider buoy deployed in the ice-free months of 1986-1989 by the Marine Environment Data Service of Environment Canada is also shown. Bathymetric contours are in fathoms. 


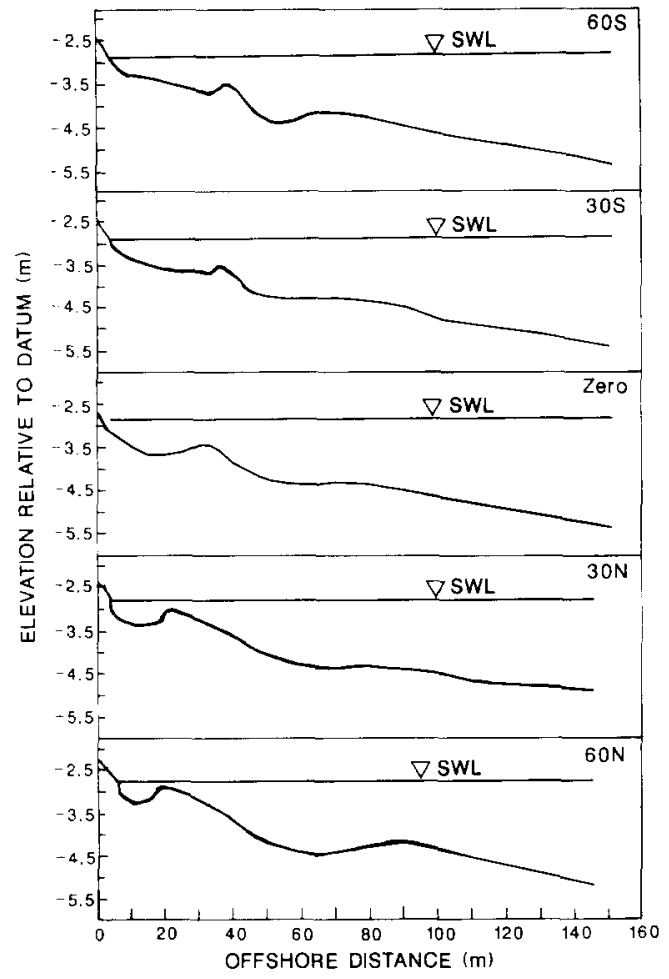

Fig.2. Beach profiles, Wymbolwood Beach, 1986. Profiles are separated by $30 \mathrm{~m}$ in the alongshore direction over the study site. Instruments were deployed along the Zero profile; note the relatively low amplitude of the outer bar and its gentle landward slope.

shore bars in medium to fine sands $(0.13-0.43 \mathrm{~mm}$ mean diameter) on a mean nearshore slope of 0.015 (Fig.2). Bar crest heights (and thus crest positions) were defined by the maximum distance perpendicular to a line of mean beach slope tangential to the bar troughs. The inner and outer bars were respectively 0.55 and $0.45 \mathrm{~m}$ high and located approximately 30 and $70 \mathrm{~m}$ offshore. The inner bar had relatively steep local slopes (landward $=0.083$; lakeward $=0.047-0.031$ ). The outer bar, in contrast, consisted of a laterally extensive, very gentle landward slope $(0.005)$ from 55 to $70 \mathrm{~m}$ offshore and a lakeward slope approximately equal to that of the mean beach slope. It is worth noting that neither of the landward slopes were close to the angle of repose during this experiment, though such slopes frequently occur in the inner bar system, especially as the bar migrates onshore and/or alongshore prior to merging with the beach face in a broad shore terrace.

\section{Experimental design}

Sensor location (Fig.3) was dictated by the number available and a desire to monitor the overall surf zone dynamics as well as the detailed fluid motions under breaking waves over one slope element, the landward (reverse) slope of the outer bar.

\section{Monitoring waves and currents}

Incident waves and mean water surface elevations were recorded with a shore-normal array of 15 ( $1.5-3 \mathrm{~m}$ long), surface piercing, continuous resistance wave staffs (modified after a design by Truxillo, 1970). The lakewardmost staff was $\sim 130 \mathrm{~m}$ offshore in $\sim 2 \mathrm{~m}$ of water (Fig.3a). Wave staffs were calibrated individually in the field and sensor output was linear except for the lowermost $0.25 \mathrm{~m}$. Local wind speed and direction, important for wave generation in this fetch-limited environment and for inducing water level setups, was measured relative to the shore-normal at the beach face using a Belfort anemometer and wind vane.

The horizontal components of flow in the shorenormal and shore-parallel directions were recorded using biaxial electromagnetic flowmeters (MarshMcBirney Model OEM 512). Nine flowmeters were deployed in a tri-level, shore-normal array across the landward slope of the outer bar (Fig. 3b) to provide a reasonable determination of the spatial and temporal coherence of the vertical structure in the local horizontal velocity field. The flowmeters in each vertical array were placed at $0.1,0.5$ and $1.0 \mathrm{~m}$ above the pre-storm bed, and the arrays separated by $5 \mathrm{~m}$ at 60,65 and $70 \mathrm{~m}$ offshore. Single flowmeters (at $0.1 \mathrm{~m}$ elevation) were deployed on the lakeward slope of the outer bar ( $\sim 110 \mathrm{~m}$ offshore) and landward of the inner bar, in the trough ( $\sim 5 \mathrm{~m}$ from the beach step). A flowmeter was deployed also on the lakeward slope of the inner bar, but proved unreliable and is not considered further. Flowmeters were calibrated individually in a large towing tank at the Canadian 

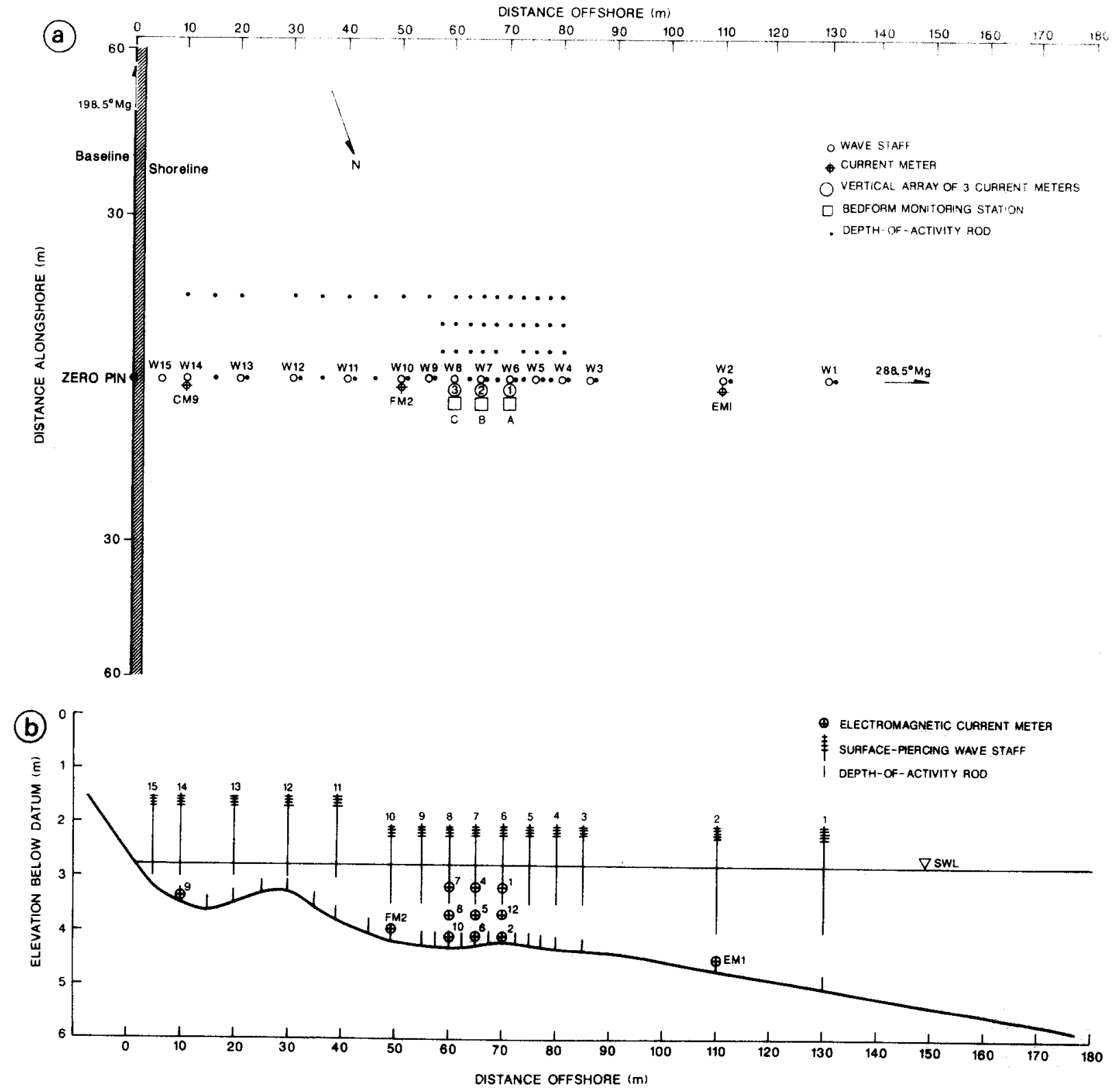

Fig.3. Instrument deployment, Wymbolwood Beach, 1986: (b) cross-section (note the numbers of the current meters - those closest to the bed (at the $0.10 \mathrm{~m}$ elevation) are used in this paper and (a) plan view (note the dense grid of depth-of-activity rods across the landward slope of the outer bar and those along lines zero and $15 \mathrm{~m}$ to the south).

National Calibration Facility (De Zeeuw, 1980); they exhibited a linear response and calibration coefficients were determined by a least squares linear regression. Considerable concern has been voiced recently over the accuracy of current measurement with the Marsh-McBirney sensors (Aubrey et al., 1984; Aubrey and Trowbridge,
1985; Hamblin et al., 1987) especially with respect to mean flows and asymmetries (see also the comments of Guza, 1988 and Aubrey and Trowbridge, 1988). However, it is now clear that the flowmeters can be used with confidence to measure mean flows greater than $\sim 0.04 \mathrm{~m} \mathrm{~s}^{-1}$ in an oscillatory flow field and that the gain error is not more 
than 5\% (Doering and Bowen, 1987a,b; Guza et al., 1988). All sensors were hardwired to a shorebased power supply and computer-controlled data acquisition system and scanned every $0.42 \mathrm{~s}$ for approximately $20 \mathrm{~min}$.

\section{Data analysis}

The first three normalized moments of the surface elevation and cross-shore velocity field were computed:

$\bar{\eta}=\frac{1}{n} \sum_{i=1}^{n} \eta_{(x, i)}$

or $\bar{u}=\frac{1}{n} \sum_{i=1}^{n} U_{(x, i)}$

$\eta_{s}=\left[\frac{1}{n-1} \sum_{i=1}^{n}\left(\eta_{(x, i)}-\bar{\eta}\right)^{2}\right]^{1 / 2}$

or $u_{s}=\left[\frac{1}{n-1} \sum_{i=1}^{n}\left(U_{(x, i)}-\bar{u}\right)^{2}\right]^{1 / 2}$

$\eta_{s k}=\left[\frac{1}{n-1} \sum_{i=1}^{n}\left(\eta_{(x, i)}-\bar{\eta}\right)^{3}\right] / \eta_{s}^{3}$

or $u_{s k}=\left[\frac{1}{n-1} \sum_{i=1}^{n}\left(U_{(x, i)}-\bar{u}\right)^{3}\right] / u_{s}^{3}$

where $\eta_{(x, i)}$ and $\boldsymbol{u}_{(x, i)}$ are the instantaneous surface elevation and shore-normal velocity, respectively, at location $x ; n$ is the sample size ( 2925 points), the overbar indicates time-averaged values and the subscripts $s$ and $s k$ refer to the standard deviation and skewness respectively. Note that the skewness computed is the normalized time-averaged third moment about the mean (as also computed by Guza and Thornton, 1985); it is therefore not identical to the time-averaged third moment of the total oscillatory velocity vector, $\left\langle\boldsymbol{u}_{\mathrm{t}}{ }^{3}\right\rangle$ as computed by Bowen (1980a,b) and Bailard (1981), which incorporates any alongshore contribution and contributions from mean flows. In this way the mean velocity (1st moment) can be considered as a distinct component of the velocity field from the velocity skewness (3rd moment), direct comparison between data records with differing means is possible and the potential for shore-normal sediment transport is emphasized. It should be noted further, that the skewness reflects wave asymmetries about both the horizontal and vertical axes (see Doering, 1988). Higher order moments (4th, 5th, etc.) were not computed because the limited record length would bias against any low-frequency fluctuations (groupiness, secondary waves, etc.) which become important to the higher moments (Doering and Bowen, 1985) and since their susceptibility to data errors leads to dramatic reductions in statistical reliability. Bailard (1987) actually uses a 5th order moment to provide a test of data reliability.

Energy spectra were computed using the BMDP2T Power Spectrum Analysis (Dixon, 1971; Dixon and Brown, 1979). Peak periods $\left(T_{\mathrm{pk}}\right.$ and $u_{\mathrm{pk}}$ ) were determined from the maximum variance spectral densities; significant wave heights were estimated from the total record standard deviations $\left(H_{\mathrm{s}}=4 \times \eta_{s}\right)$.

\section{Monitoring sediment flux and morphological change}

Local sediment reactivation depths, estimates of total and net sediment flux, as well as precise bed elevation and slope changes were measured with depth-of-activity rods. Figure 4 summarizes the measurements made by divers and the flux computations (for full description and tests of rod accuracy, see Greenwood and Hale, 1980; Greenwood et al., 1980). Sixty-five steel rods, $0.5 \mathrm{~cm}$ in diameter, were deployed in total (Fig.3) with the greatest density in a subset across the landward slope of the outer bar ( 42 rods covering an area of $550 \mathrm{~m}^{2}$ ). Other subsets were used to monitor the inner bar and the lakeward slope of the outer bar (Fig.3a). Nominal control volumes for each zone were determined by taking the areal extent of the grids and multiplying by a standard $0.5 \mathrm{~m}$ depth of sand. The latter is a reasonable depth for potential "reactivation", considering the bar heights and their ability to migrate.

Large-scale morphological changes were monitored by surveying shore-normal lines at $30 \mathrm{~m}$ intervals alongshore (Fig.2). A Raytheon Fathometer (Model DE719) recorded depths from approximately $50 \mathrm{~m}$ offshore (depth $1 \mathrm{~m}$ ) to $1000 \mathrm{~m}$ offshore (depth $7 \mathrm{~m}$ ). Depths less than $1.75 \mathrm{~m}$ and the beach face were surveyed using a 


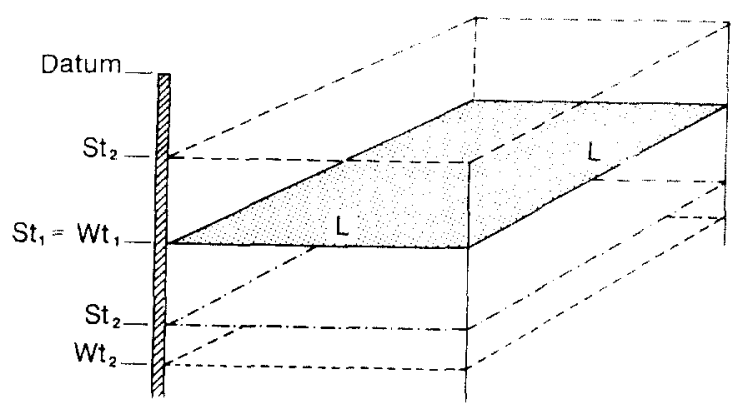

Depth-of-Activity $=\mathrm{St}_{1}-\mathrm{Wt}_{2}$ or $\mathrm{St}_{2}-\mathrm{Wt}_{2}$

Bed Elevation Change $=\mathrm{St}_{2}-\mathrm{St}_{1}$

Time - integrated Total Volume Flux $=\left[W t_{2}-W t_{1}\right] . L^{2}$ (ITVF) or $=\left[\mathrm{Wt}_{2}-\mathrm{St}_{2}\right] \cdot \mathrm{L}^{2}$ if $\mathrm{St}_{2}<\mathrm{St}_{1}$

Time - integrated Net Volume Flux $=\left[S t_{1}-S_{2}\right] \cdot L^{2}$ (INVF)

$$
\begin{aligned}
& S=\text { Surface elevation relative to top of rod } \\
& W=\text { Washer elevation relative to top of rod } \\
& t_{1}, t_{2}=\text { Time steps } \\
& L=\text { Unit length }
\end{aligned}
$$

Fig.4. Depth-of-activity rod measurements and computations for estimating sediment flux (ITVF and INVF are volumes).

level and staff; elevations were corrected to an arbitrary datum $2.78 \mathrm{~m}$ above the average still water. Detailed bathymetric adjustments were resolved using the depth-of-activity rod measurements along certain transects.

\section{Storm event: June 16-18, 1986}

A meteorological depression tracking northeastward across Georgian Bay, June 16-18, 1986, generated waves which propagated into the experimental site for a period of $49 \mathrm{~h}$. A synthetic deep water wave climatology for Nottawasaga Bay, based on 14 years of meteorological data from Cove Island (Fig.1) and SMB hindcasting procedures (see Hale and Greenwood, 1980) is available from Brander (1988). A partial duration series of significant wave height suggests a return period for this storm of only 0.2 yrs. This storm was not, therefore, an extreme event with respect to wave size; however, owing to the gentle slope of the upper shoreface, depth-controlled wave break- ing is reached quickly in storms and the surf zone extends several hundreds of meters offshore, well lakeward of the outer bar. Furthermore. wave height and period quickly become fetch limited: deep-water waves entering Nottawasaga Bay recorded over 2 years by the Marine Environmental Data Service of Environment Canada (Fig.1) do not exceed $3 \mathrm{~m}$ in height or $8 \mathrm{~s}$ in period (pers. commun., 1989). The effect of storm magnitude in the nearshore is, therefore, to control the duration of wave breaking in the upper shoreface. It also may constrain the generation of low-frequency oscillations (edge waves, seiches, etc.), wind stress currents and the amount of wind and wave setup at the shoreline.

Temporal variation in wind speed and direction at the beach face and significant wave height and peak period, measured at the outermost wave staff are presented in Fig.5. Direct observation, together with use of a realistic breaking criterion $(0.45$ for undulatory bores; for review see Cowell, 1982), indicate that the surf zone extended well beyond the outer bar for a period of at least $11 \mathrm{~h}$ and that breaking was present on the outer bar crest and the area landward for a significantly longer period. It is important to note however that the peak incident energy conditions and the associated wave-induced near-bed oscillatory currents were confined between $1300 \mathrm{~h}$ on June 16 and $0300 \mathrm{~h}$ on June 17 (Fig.5).

Maxima in wind speed and wave height were nearly in phase during this storm (peak wave height lags peak wind speed by only $0.5 \mathrm{~h}$, Fig.5) owing to the coincidence of winds with the maximum effective fetch (west-northwest). The reduction of wave height following the storm peak at $1800 \mathrm{~h}$ can be attributed to a reduction in wind velocity as well as to a shift in the wind direction to the north and northwest away from the maximum fetch. Breaking waves were present on the upper shoreface by $1300 \mathrm{~h}$ on June 16 under $7 \mathrm{knot}$ $\left(13.5 \mathrm{~m} \mathrm{~s}^{-1}\right)$ winds from the southwest. Winds from the west-northwest increased to a maximum of 20 knots $\left(38.5 \mathrm{~m} \mathrm{~s}^{-1}\right)$, at $1730 \mathrm{~h}$ generating significant wave heights of $1.5 \mathrm{~m}$ by $1800 \mathrm{~h}$ with a peak period of 5.5-6s. Passage of the frontal system caused winds to veer to the north-northwest and north at $2000 \mathrm{~h}$ with speeds of 15 knots 

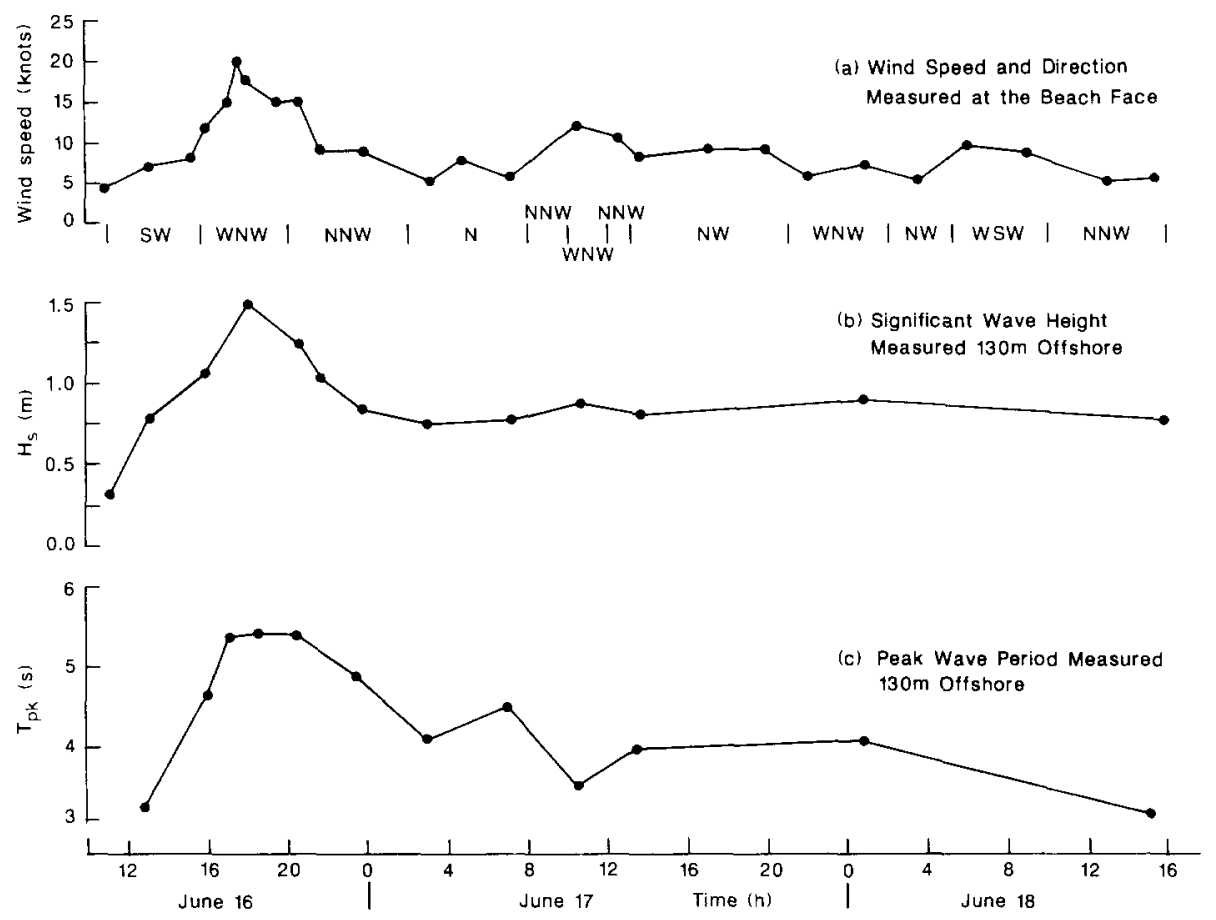

Fig.5. Wind and wave conditions, Wymbolwood Beach, June $16-18,1986 . H_{\mathrm{s}}=$ significant wave height and $T_{\mathrm{pk}}=$ peak period, both measured $130 \mathrm{~m}$ offshore.

$\left(28.8 \mathrm{~m} \mathrm{~s}^{-1}\right)$ which decreased to 5 knots $\left(9.62 \mathrm{~m} \mathrm{~s}^{-1}\right)$ by $0300 \mathrm{~h}$ on June 17 . Wave heights decreased to $1.26 \mathrm{~m}$ by $2030 \mathrm{~h}$ (June 16) and $0.75 \mathrm{~m}$ $6 \mathrm{~h}$ later, when the peak period also dropped to $4 \mathrm{~s}$; waves remained approximately at this height and period under moderate winds for the remainder of the storm. Waves were therefore wind forced with no propagation of swell from long distances. Although wave activity lasted for $49 \mathrm{~h}$, the largest waves were confined to the first $12 \mathrm{~h}$ of the storm.

\section{Morphodynamic response of the nearshore slope}

Figure 6 illustrates pre- and post-storm profiles together with a profile from later in the season from the instrument transect (Line 0). The outer bar remained virtually unchanged as a result of this storm and through until June 24, even though another storm occurred between June 19 and 23. Indeed the crest location and form of this outer bar had remained essentially the same since May 16, even though several small storms passed through the area during this time. More specifically, the landward slope experienced no measureable change.

The inner bar, in contrast, migrated onshore along Line 0 , with the crest advancing $\sim 6 \mathrm{~m}$ landward of its pre-storm position. This was associated with erosion of both the lakeward slope, landward side of the trough and the beach face. Fifteen meters to the south however, the crest remained stable resulting in a three-dimensional sinuous form. A cuspate shoreline rhythm was observed forming at $0430 \mathrm{~h}$ on June 17, well past the storm peak, with horns at $60 \mathrm{~m}$ and $120 \mathrm{~m}$ north of Line 0 . By $1330 \mathrm{~h}$ on the same day these horns had increased in size and the inner bar at these locations was now only $\sim 2 \mathrm{~m}$ from the beach step. One day later ( $1200 \mathrm{~h}$, June 18$)$, the inner bar had migrated along Line 0 to a position less than $16 \mathrm{~m}$ from the beach step; since the pre-storm crest position was $26 \mathrm{~m}$ from the step, and allowing for some small lakeward progradation of the beach face and step, the bar had therefore migrated $\sim 10 \mathrm{~m}$. The inner bar at $60 \mathrm{~m}$ and $120 \mathrm{~m}$ north of this line had actually attached itself to the beach by this time. 


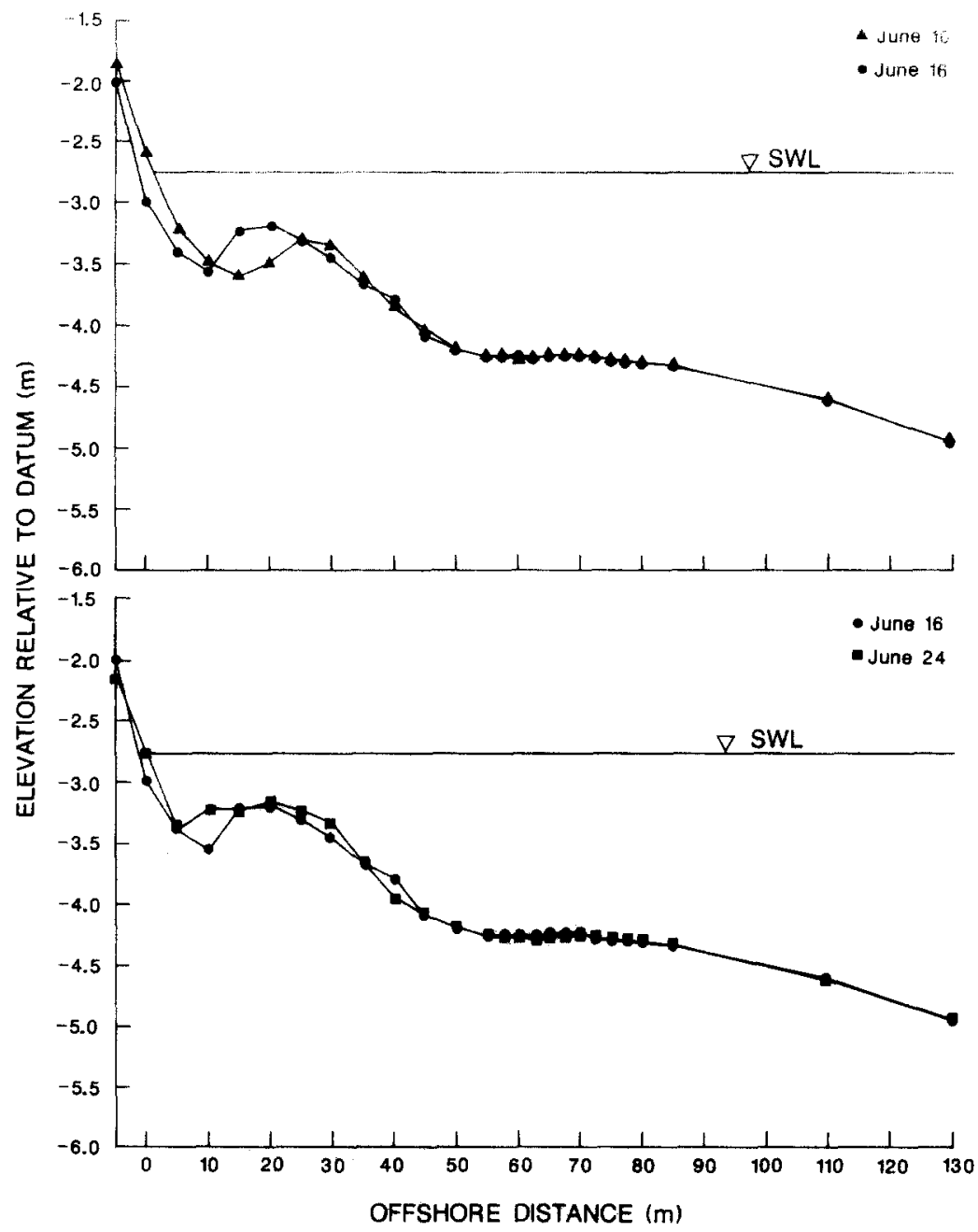

Fig.6. Pre- and post-storm profiles. The profiles are for the instrument transect (Line 0 ) and are based on a survey on June 10 and subsequent elevations based upon depth-of-activity rod measurements. A profile for later in the season following a storm on June $22-24$ is also shown.

Although it was impossible to monitor continuously the morphodynamic behaviour of either bar during the storm peak, rod measurements reveal that the outer bar was extremely stable in position and form, while the inner bar was significantly more dynamic, exhibiting both form and positional changes. However, beach observations support the contention that these adjustments were restricted to the period after the storm peak.

\section{Sediment flux and bed elevation change}

Depths of sediment reactivation and bed elevation changes over the two nearshore bars are shown in Fig.7. Sediment volume fluxes computed for the upper shoreface as a whole, the inner bar system $(5-50 \mathrm{~m})$, the landward slope $(55-90 \mathrm{~m})$ and the outer bar as a whole $(55-130 \mathrm{~m})$ are summarized in Table 1. Substantial sediment reactivation occurred over the nearshore slope, with depths-of-activity relative to the pre-storm surface ranging from 6 to $42 \mathrm{~cm}$. The time-integrated total volume flux of sediment (ITVF $=85 \mathrm{~m}^{3}$ ) represents reactivation of $27 \%$ of the nominal control volume of the complete bar system; in contrast the timeintegrated net volume flux of sediment (INVF $=-0.63 \mathrm{~m}^{3}$ ) was only $0.2 \%$ of the nominal control volume. The outer bar alone experienced a 


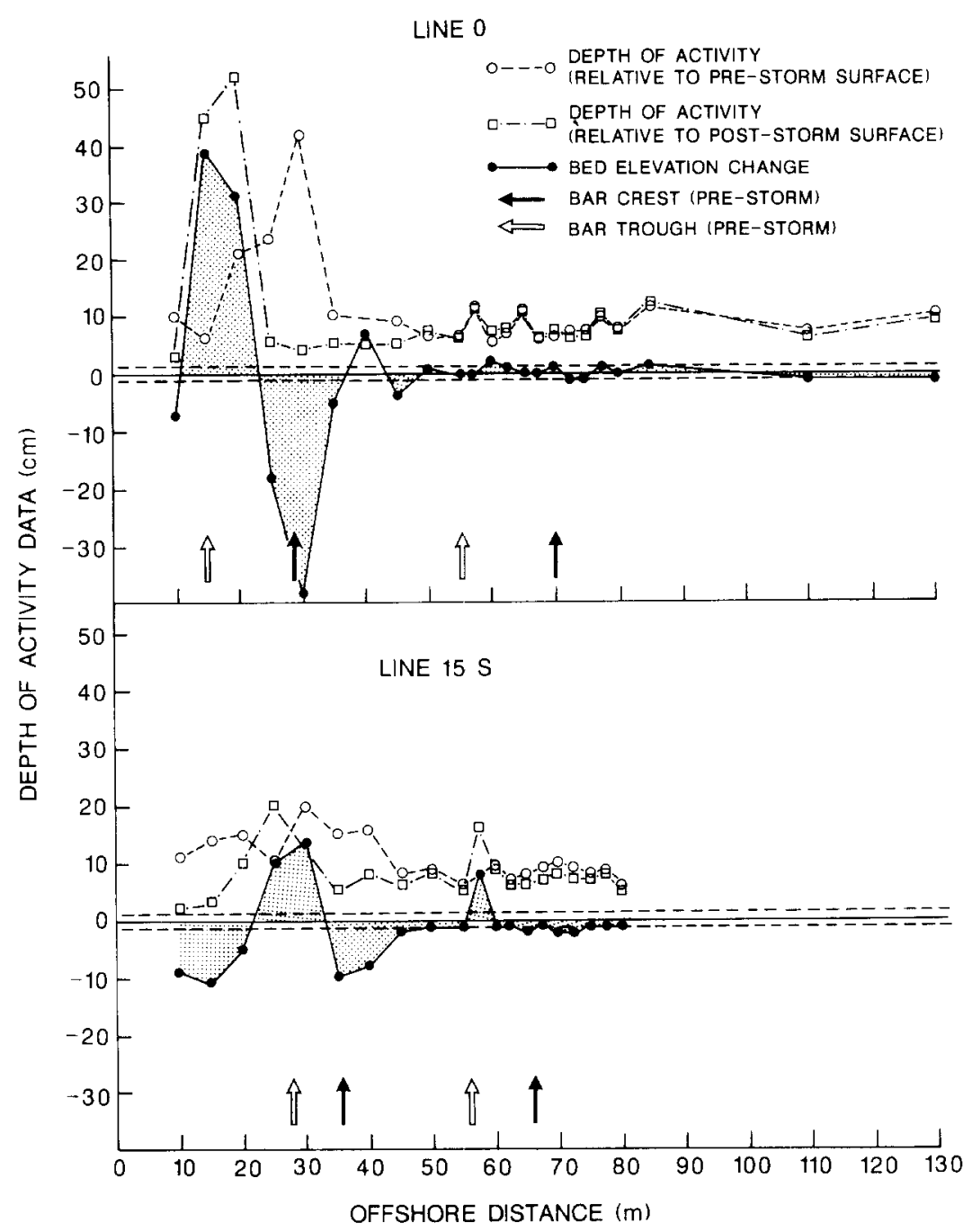

Fig.7. Depth-of-activity and bed elevation changes along the instrument transect (Line 0 ) and a transect $15 \mathrm{~m}$ to the south (Line $15 \mathrm{~S}$ ). Measurements relative to both the pre-storm and post-storm surface are illustrated as are the pre-storm locations of the bar crests and troughs. The dashed horizontal lines represent the potential measurement crror band around zero bed elevation change.

$17 \%$ reactivation of the partial control volume, with essentially uniform depths of reactivation over both landward and lakeward slopes; the net volume flux of sediment (INVF) was again less than $1 \%$ of the control volume. Sediment reactivation in the inner bar was significantly higher than in the outer bar; $32-51 \%$ of the partial control volume (depending on the shore-normal transect considered) was reactivated. The net volume flux of sediment (INVF) was also larger $(2 \%$ on average), but variable alongshore (Table 1), reflecting erosion and accretion associated with develop- ment of the three-dimensional form. This net flux was, however, still extremely small. Both bars, therefore, exist within a sand prism which, at least in the short term $\left(\sim 10^{-1} \mathrm{yrs}\right)$, is in a "steady state", supporting the earlier conclusions of Greenwood (1987).

\section{Outer bar slopes}

In the outer bar, bed elevation changes were negligible (Fig.7); 70\% of the rod measurements on the landward slope showed changes less than 
TABLE 1

Estimates of nearshore sediment flux

\begin{tabular}{|c|c|c|c|c|}
\hline Location & $\begin{array}{l}\text { ITVF* } \\
\left(\mathrm{m}^{3}\right)\end{array}$ & $\begin{array}{l}\text { INVF* }^{*} \\
\left(\mathrm{~m}^{3}\right)\end{array}$ & mobilized & $\begin{array}{l}\% \\
\text { change }\end{array}$ \\
\hline $\begin{array}{l}\text { Total nearshore prism } \\
\text { (line zero) }\end{array}$ & 85 & -0.63 & 27 & 0.20 \\
\hline \multicolumn{5}{|l|}{ Ouler bar } \\
\hline Total (line zero) & 34 & -0.62 & 17 & -0.31 \\
\hline Landward slope $(0)$ & 11 & 0.39 & 15 & 0.52 \\
\hline Landward slope (15 S) & 12 & -0.65 & 16 & -0.87 \\
\hline Average: & 12 & -0.13 & 16 & -0.18 \\
\hline
\end{tabular}

Inner bar

(0)

$(15 \mathrm{~S})$

\begin{tabular}{|c|c|c|c|c|}
\hline & 51 & 1.25 & 45 & 1.11 \\
\hline & 32 & -5.50 & 28 & -4.89 \\
\hline iverage: & 42 & -1.62 & 37 & -1.8 \\
\hline
\end{tabular}

*ITVF and INVF refer to the time-integrated total and timeintegrated net volume fluxes of sediment respectively

$\pm 1 \mathrm{~cm}$, which is within the error band for the measurements. Also the range of relief induced by single wave ripples is of the same order and ripples of such size $(\leqslant 2 \mathrm{~cm})$ are always present on the post-storm surface. Thus the local slopes and hence the outer bar morphology remained essentially unchanged. Since significant sediment reactivation did occur, with a maximum depth of $14 \mathrm{~cm}$ (Fig.7), the bar form could be considered to be in a "steady state" in the presence of considerable sediment transport (estimated from rod data to be $\sim 0.14 \mathrm{~m}^{3} \mathrm{~m}^{-2}$ ).

Post-storm box cores (Greenwood et al., 1984) from the flowmeter locations on the landward slope of the outer bar revealed bedding within the storm reactivation layer reflecting sedimentation associated most probably with the post peak reduction in near-bed velocities (Fig.8). At this time any sediment redistribution would most likely be manifested. The structural signatures were those expected with a falling flow regime (Greenwood and Sherman, 1987). Sets of landward dipping, medium-scale cross lamination (= oscillation megaripples) were dominant and succeeded vertically by small-scale cross lamination (= oscillation ripples) with occasional preservation of the geneti- cally related ripple mark itsell. Only at the location closest to the bar crest $(70 \mathrm{~m}$. Fig.3) was planat lamination ( = flat bed/sheet flow) identifiable within the storm reactivation layer and even here it was a thin unit $(<0.01 \mathrm{~m})$. During the oscillation megaripple phase, net sediment transport tat least bedload) was shoreward, but it is impossible to determine how significant this was in volumetric terms. Small-scale surface ripples, developed at the termination of the storm, showed structural evidence for both landward (dominant) and lakeward migration indicating some small shifts in the directionality of the net transport at this stage: however, the amounts of sediment moved would have likely been small. The directionality of net sediment motion associated with any flat bed phase is unknown, although it is clearly possible that transport rates at this stage would be the most significant. Since the lower regime structures in general indicated a net landward transport of sediment (at least of bedload), then the sediment balance was achieved either by offshore transport during the flat bed phase or by suspension transport at any time.

\section{Inner bar slopes}

Along the instrument line (Line 0), up to $40 \mathrm{~cm}$ of sediment was eroded from the lakeward slope of the inner bar and a similar accretion occurred on the landward slope (Fig.7). The near equality of volumes involved is consistent with a simple landward displacement of sediment, which was reflected in the landward migration of the bar form. Along transect $15 \mathrm{~S}$, however, erosion of both lakeward and landward slopes occurred (of the order of $10 \mathrm{~cm}$ ) associated with a vertical accretion of the bar crest (Fig.7). Local steepening of slopes resulted from both the migration and vertical accretion of the inner bar.

\section{Local hydrodynamics}

To understand the fluid dynamics and kinematics which induced motion of large volumes of sediment with near-zero net transport and no morphological change in the outer bar, while at the same time inducing significant changes in the inner bar, the local near-bed currents will be examined. 

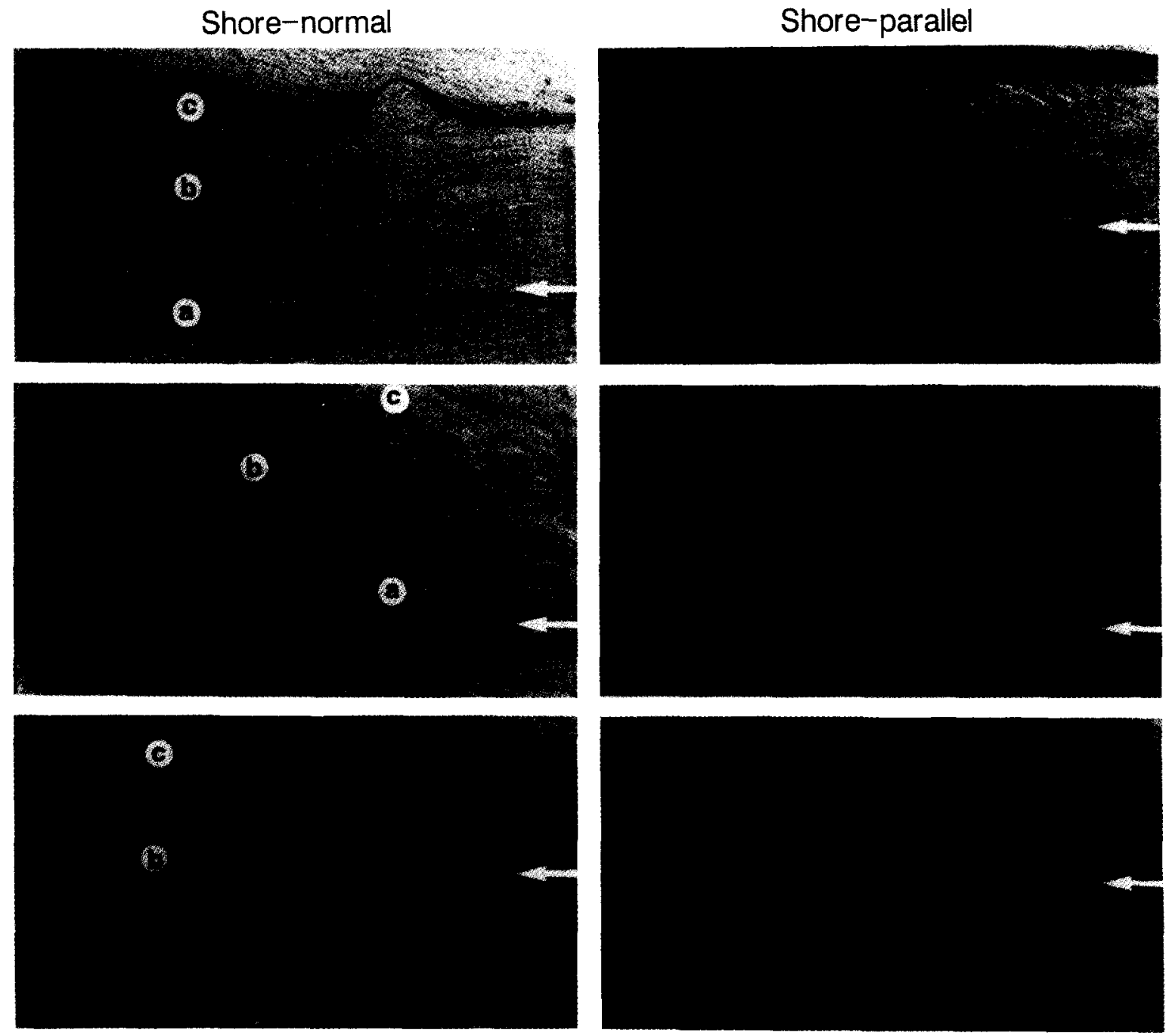

$60 \mathrm{~m}$

\section{$.10 \mathrm{~m}$}

Fig.8. Epoxy relief peels of box cores from the landward slope at $60-70 \mathrm{~m}$ offshore. The peels on the left are oriented in a shore-normal direction, with the shoreline to the left; the peels on the right are oriented in a shore-parallel direction with north being to the right. The depth-of-reactivation relative to the post-storm surface is marked by the arrows. $a=$ planar lamination: $b=$ medium-scale trough cross lamination; $c=$ small-scale trough cross lamination.

Especially important are the cross-shore components of the velocity field which must represent a first approximation to the sediment transport potential of the system.

\section{Cross-shore velocities: outer bar}

Figure 9 illustrates a time series of frequency distributions of the cross-shore velocity vector $\left(\boldsymbol{u}_{x, i}\right)$ measured at an elevation of $0.10 \mathrm{~m}$ at the three locations across the landward slope of the outer bar. Several characteristics relevant to sediment transport are revealed.

First, the oscillatory currents alone were well in excess of the threshold for motion of the local sand (conservatively taken as $0.20 \mathrm{~m} \mathrm{~s}^{-1}$ ), throughout the full storm period. Furthermore, for the grain sizes present on the landward slope of the outer bar 
$\mathrm{CM} 2$

LAKEWARD
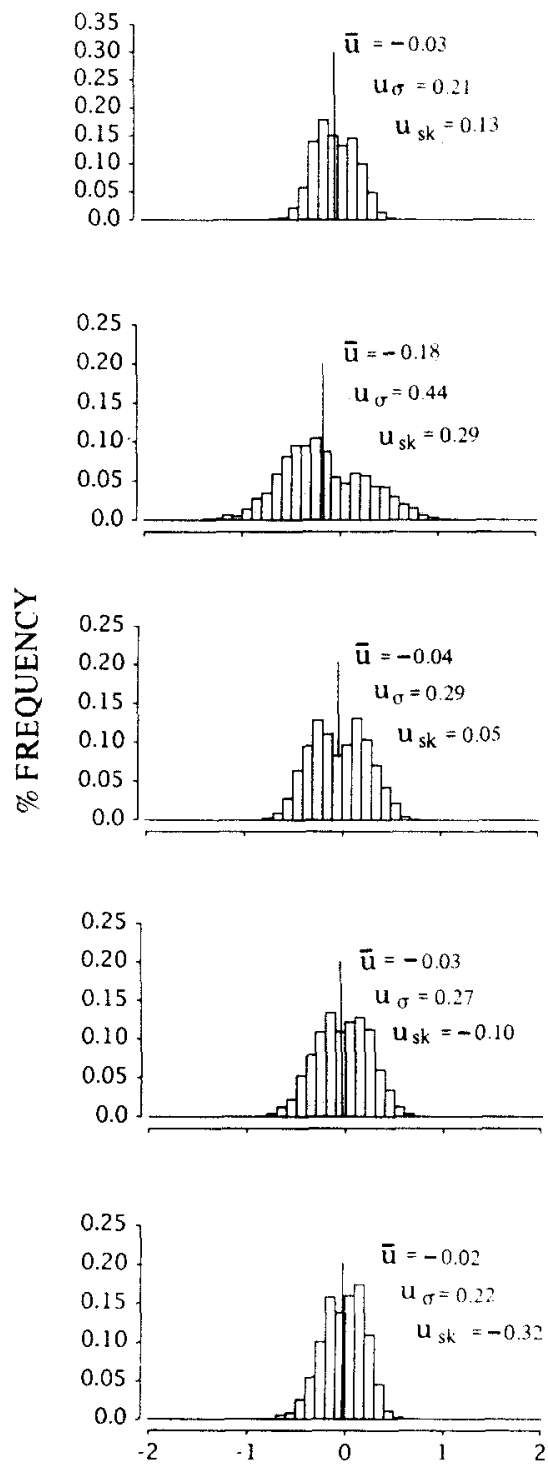

CM6

$06: 16 \quad 13001 \mathrm{~h}$

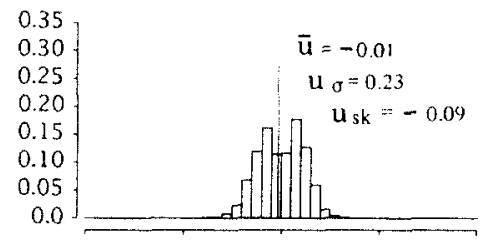

$1800 \mathrm{~h}$
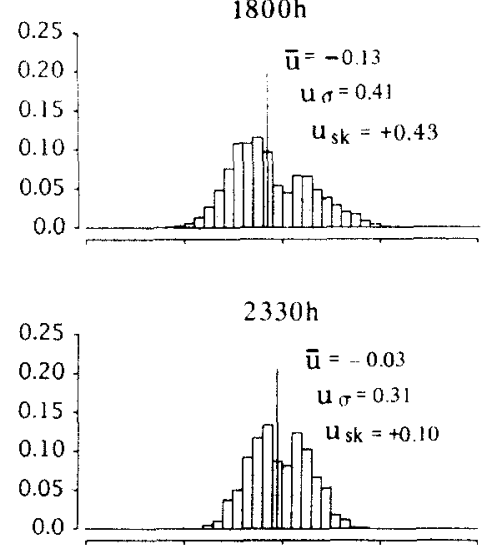

06:17 1300h

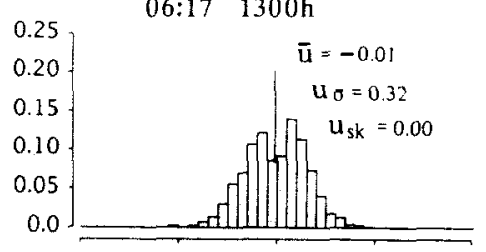

$06: 18 \quad 1600 \mathrm{~h}$

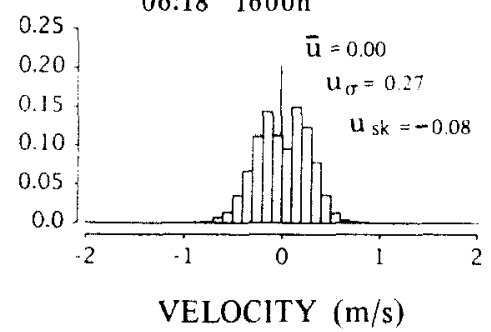

CMlO

LANDWARD
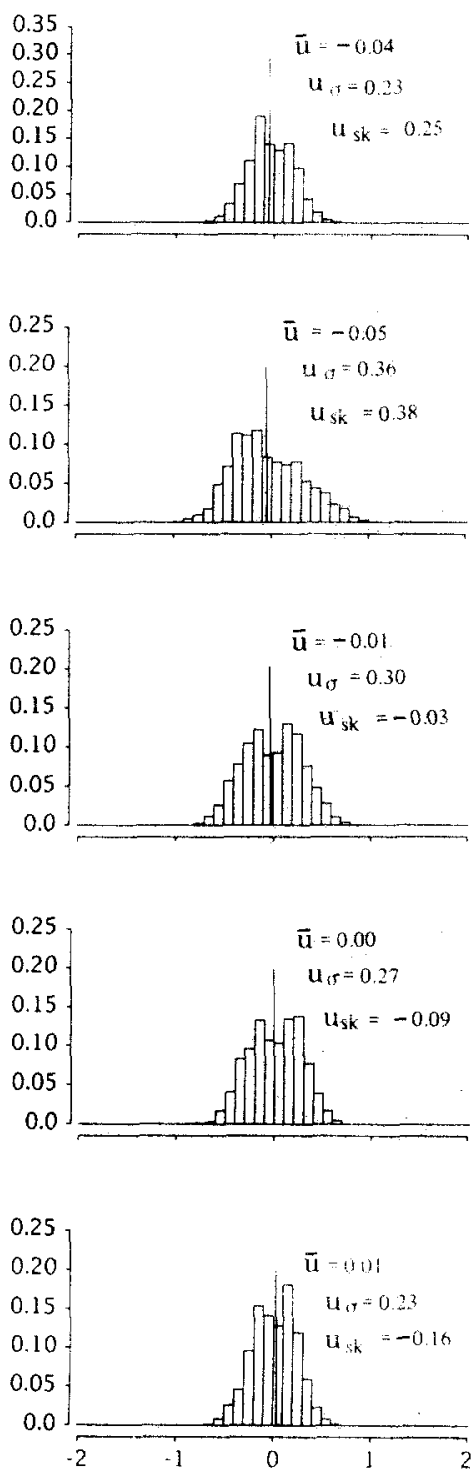

Fig.9. Frequency distributions of the cross-shore velocity vector at the $0.10 \mathrm{~m}$ elevation across the landward slope of the outer bar. Shown are the flowmeter records for $70 \mathrm{~m}(\mathrm{CM} 2), 65 \mathrm{~m} \mathrm{(CM6)}$ and $60 \mathrm{~m}(\mathrm{CM} 10)$ at different times through the full storm cycle. The means of the distributions are marked by an extended ordinate, and included are the magnitudes of the mean flows $(\bar{u})$, the standard deviation of the velocity vectors $\left(u_{\sigma}\right)$ and the velocity skewness $\left(u_{s k}\right)$.

(mean diameter $\sim 0.20 \mathrm{~mm}$ ), instantaneous nearbed velocities exceeded even the accepted threshold for sheet flow/flat bed transport during the peak of the storm; using Dingler and Inman's (1977) threshold criterion, this value would be $\sim 0.90 \mathrm{~m} \mathrm{~s}^{-1}$ ), while Allen's (1985) research would suggest a value as low as $\sim 0.60 \mathrm{~m} \mathrm{~s}^{-1}$. Taking the more recent estimate for the sheet flow/flat bed threshold for oscillatory flows, then during the storm peak such flows were exceeded $\sim 15 \%$ of the 
time. Indeed, instantaneous flows above this threshold occurred as early as $1600 \mathrm{~h}$ and as late as $2330 \mathrm{~h}$, June 16 , but were present for less than $5 \%$ of the time. However, it is also clear from other field observations (Sherman and Greenwood, 1984; Greenwood et al., 1985; Greenwood and Sherman, 1986b, 1987) that in the complex combined flows of the upper shoreface, large bedforms can exist under near-bed flow velocities well in excess of the flat bed threshold derived primarily from laboratory measurements. Diver observations at $1730 \mathrm{~h}$ revealed occasional sheet flow during lakeward surges associated with large waves; bed stabilization, but not ripple regeneration, occurred during passage of the associated landward surges. Thus flat bed/sheet flow transport did occur at times, as also indicated by the structural signatures, but it would appear to have been severely restricted in time.
Second, individual velocity distributions were typically near-Gaussian for much of the time. During the period of maximum velocities and greatest energy dissipation, however, a markedly non-Gaussian distribution occurred with two distinct asymmetries: a large mean offset from zero and a marked skewness. The mean flow was offshore, with speeds up to $0.20 \mathrm{~m} \mathrm{~s}^{-1}$; coincident in time with this asymmetry was a large positive (onshore) skewness in the velocity field.

Variability of flow asymmetries: outer har

Figure 10 illustrates time series of the near-bed $(0.1 \mathrm{~m})$ cross-shore velocity moments $\left(u_{\mathrm{s}}, \bar{u}, u_{\mathrm{sk}}\right)$ from the outer bar system. Measured flows were strongly coherent temporally and nearly identical orbital speeds were recorded at the beginning and end of the storm peak on the landward slope, at
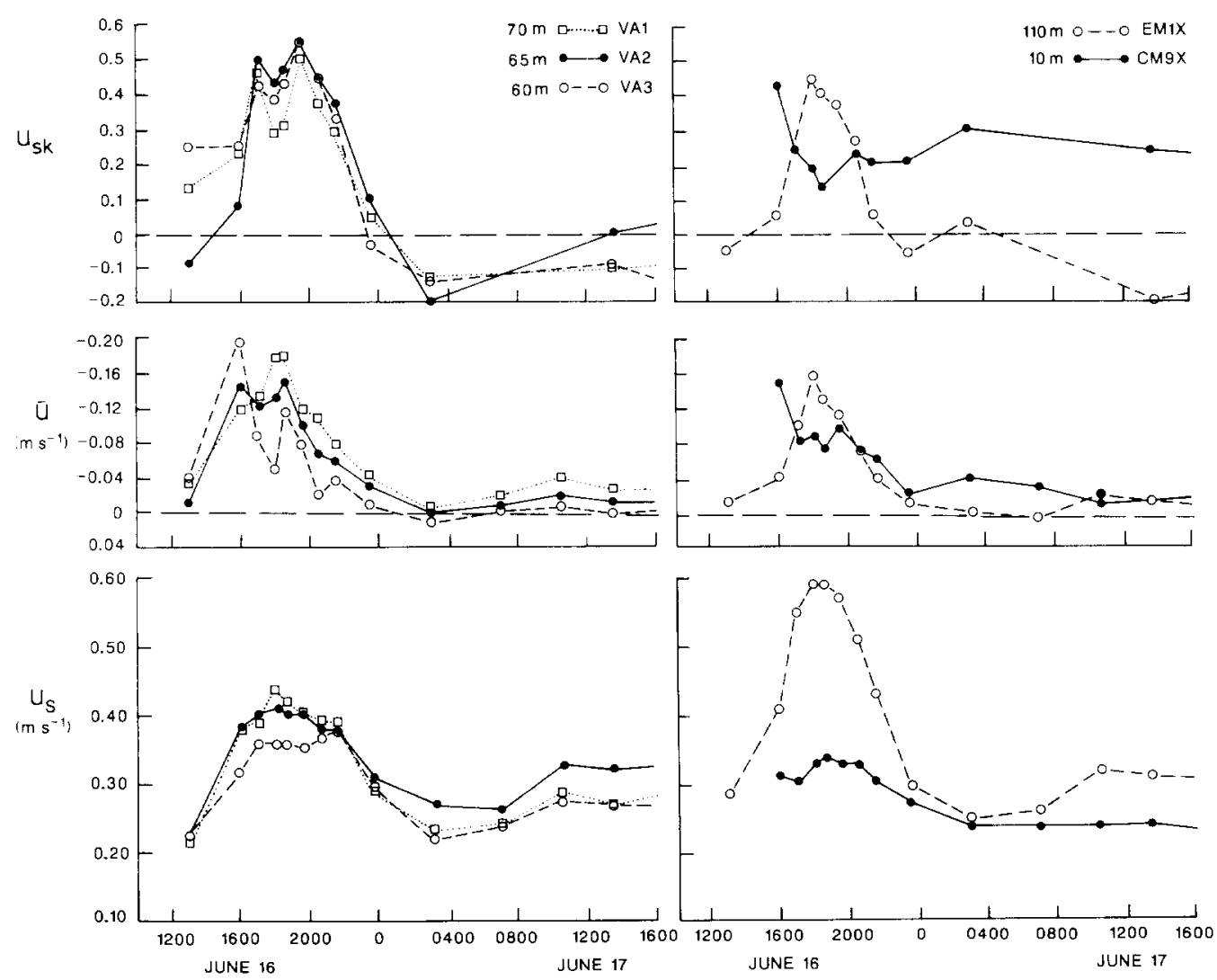

Fig. 10. Time series of orbital velocity $\left(u_{s}\right)$, mean flow $(\bar{u})$ and velocity skewness $\left(u_{s k}\right)$ for the $0.10 \mathrm{~m}$ elevation across the landward slope of the outer bar (at 60,65 and $70 \mathrm{~m}$ ), on the lakeward slope of the outer bar at $110 \mathrm{~m}$, and in the inner bar trough $10 \mathrm{~m}$ from the baseline. 
limes when waves would be shoaling rather than breaking at this location. The latter gives confidence in the instrument performance and credibility to the variation in measured currents during more energetic conditions. A small increase in gain in the flowmeter at $65 \mathrm{~m}$ appeared on June $17-18$; although the trends were coherent with other sensors close by, speeds will be overestimated.

As noted earlier, local orbital velocities $\left(u_{\mathrm{s}}\right)$ at all stations were well in excess of the threshold for motion for the local sand throughout the storm. peaking between $1700 \mathrm{~h}$ and $1800 \mathrm{~h}$ on June 16 when maximum flows $\left(2.8 \times u_{\mathrm{s}}\right)$ were well above the threshold for sheet flow. Even as late as $1600 \mathrm{~h}$ on June 18, near-bed flows would have maintained sand in motion. Cross-shore velocities during the storm peak were a maximum at the outermost station and decreased landward as a result of energy dissipation due to wave breaking and propagation into slightly deeper water in the trough.

From $1300 \mathrm{~h}$ until $2330 \mathrm{~h}$ on June 16 an offshore mean flow was superimposed on the oscillatory motion, reaching a maximum of $0.20 \mathrm{~ms}^{-1}$ at the $60 \mathrm{~m}$ station. This strong current was not restricted to the landward slope; temporally coherent offshore flows were observed on the lakeward slope of the outer bar and landward of the inner bar (Fig. 10). It is significant that during the early part of the storm, when waves built from the southwest for a short time, this time-averaged mean flow decreased lakeward from $0.20 \mathrm{~m} \mathrm{~s}^{-1}$ to $0.12 \mathrm{~m} \mathrm{~s}^{-1}$ over a distance of $10 \mathrm{~m}$ across the landward slope so that the flow was detectable but small $\left(0.04 \mathrm{~m} \mathrm{~s}^{-1}\right)$ at the $110 \mathrm{~m}$ station. At the storm peak, with expansion of the surf zone width, velocities increased lakeward across the landward slope from $0.12 \mathrm{~m} \mathrm{~s}^{-1}$ to $0.18 \mathrm{~m} \mathrm{~s}^{-1}$ and were of the same order at the $110 \mathrm{~m}$ station. After $2330 \mathrm{~h}$ on June 16 the mean flows were less than $0.04 \mathrm{~m} \mathrm{~s}^{1}$; if we accept this value as a conservative estimate of flowmeter accuracy due to rectification problems (Cunningham et al., 1979) it would suggest that at this time mean flows were essentially zero.

Coincident in time with the offshore mean flow was a large positive (onshore-directed) skewness in the cross-shore velocity field. Skewness increased dramatically after $1600 \mathrm{~h}$ but returned to near zero by $2330 \mathrm{~h}$; this increase in velocity asymmetry coincided with the continuous propagation of spilling breakers through the array and is undoubtedly due to the non-linear nature of the surface waves at this time. No statistically significant difference in the time and depth-averaged skewness could be discerned between the three stations on the landward slope separated as they were by only $5 \mathrm{~m}$; a statistically significant difference was identified between the near-bed skewness averaged through the storm peak and that higher in the water column. The time-averaged near-bed velocity skewness was approximately $40 \%$ lower than the velocity skewness in the water at an elevation of $0.50 \mathrm{~m}$. Finally, it should be noted that the velocity field across the outer bar was nearsymmetric with a near zero mean flow for much of the storm, even when spilling breakers had been initiated to lakeward. Only during the periods of most intense wave breaking was the cross-shore velocity field strongly asymmetric.

\section{Cross-shore velocities: inner bar system}

Owing to malfunction of the flowmeter on the lakeward slope of this bar, the structure of flow within the inner system can only be identified within the trough (CM9, Fig.3). Figure 10 illustrates the time series of cross-shore velocity moments through the storm at this location. It is evident that oscillatory velocities, as expressed by $u_{\mathrm{s}}$, were much lower than over the outer bar and this can be attributed almost totally to the dissipation of wave energy through breaking and friction as waves propagated onshore. At the storm peak (1800 h) for example, significant wave height had been reduced to $0.54 \mathrm{~m}$ at this location from $1.50 \mathrm{~m}$ in the outer surf zone (130 $\mathrm{m}$ offshore). Nevertheless, flow velocities were certainly large enough to maintain sediment in motion throughout the storm cycle. Significant offshore mean flows mirroring those of the outer system (Fig.10) occurred at this location also; speeds up to $0.15 \mathrm{~m} \mathrm{~s}^{-1}$ occurred after breaking had been initiated on the inner bar early in the storm. The major distinctions between the velocity field at this location and that of the outer surf zone, however, were: (1) the decrease in positive skewness through the period of wave growth to the 
storm peak, and (2) the increase and persistence of large positive (onshore) skewness values through the storm decay period of June 17. The former supports the observations of Guza and Thornton (1985) that skewness increases with shoaling to a maximum at the point of initial wave breaking (at this time over the outer bar) and thereafter decreases shoreward. The latter correlates well with the observed development of strongly translatory bores associated with wave breaking in these small water depths across the inner bar and their persistence long after the storm peak had passed.

\section{Forcing of near-bed flows}

The relatively large magnitude, spatial uniformity and temporal coherence of the cross-shore mean velocity indicate a spatially extensive lakeward flow typical of either the drift velocities associated with a low-frequency wave or an undertow, rather than a local rip current. It has been suggested by many authors that the crossshore velocity field under dissipative wave conditions may be dominated by infragravity waves for a review see Bowen and Huntley (1984). Surface elevation and cross-shore velocity spectra show that levels of energy decreased landward across the surf zone (Fig. 11) as expected from the wave height decay associated with breaking noted earlier. At $1800 \mathrm{~h}$, for example, surface wave energy in the peak incident band was reduced by $75 \%$ across $45 \mathrm{~m}$ of the outer surf zone and by a further $40 \%$ across $55 \mathrm{~m}$ of the inner surf zone. There was, however, an increase in the relative importance of low-frequency energy $(<0.10 \mathrm{~Hz})$ close to the shoreline, which persisted into the decay period (Fig.11). This energy was broad banded with no clear spectral structure; it was most probably due to the presence of either leaky or trapped long waves (or both), but such modes are notoriously difficult to isolate. An offshore drift could theoretically have resulted from either of such waves; however, the outer bar was clearly dominated by energy at the incident frequency and no well structured, discrete low-frequency peaks were present in any of the spectra from these locations. Statistical coherence was large between the cross-shore velocity and water surface eleva- tion at incident frequencies but negligible at low frequencies (Greenwood and Osborne, 1990). Since the low-frequency signal was small and failed to exhibit any significant structure across this section of the surf zone, it is unlikely to have been responsible for the measured mean flows. The variable nature of the sedimentary response of the inner bar to the storm in the alongshore direction (the development of a sinuous crest) suggests the possibility of edge wave influence; with the present data set it is impossible to confirm or reject this hypothesis. However, analysis of the vertical structure of the velocity field and the wave-induced setup of the mean water surface by Greenwood and Osborne (1990) confirms the view that the mean flow is an undertow. Mean flow speeds across the outer bar were shown to be highly correlated with the measured setup across the inner surf zone (an average $R^{2}=0.60$ for the three measurement locations). Wind and wave-induced setup reached a maximum of $0.35 \mathrm{~m}$ at the innermost wave staff (Fig.3) during the storm peak $(1800 \mathrm{~h})$ and was itself strongly correlated $\left(R^{2}=0.86\right)$ with the incident wave height. Therefore, the measured velocities in this area during the storm were associated primarily with the asymmetrical incident wave oscillations and a superimposed steady flow induced by wave-driven setup.

\section{Sediment transport potential}

The direction and rate of sediment transport induced by the velocity field over the storm depends upon rather complex and poorly understood time-dependent relationships between the instantaneous velocity vector and sediment concentration (both bedload and suspended load). Unfortunately, in this study the sediment loadings could not be determined and indeed such measurements are still difficult for suspension and virtually impossible for bedload with present technology. Nevertheless, since the velocity field provides the basic forcing function for transport, it should also provide a first approximation to the potential transport divergence patterns controlling the morphological "equilibrium" identified on the outer bar. Also realistically, velocity will remain the 


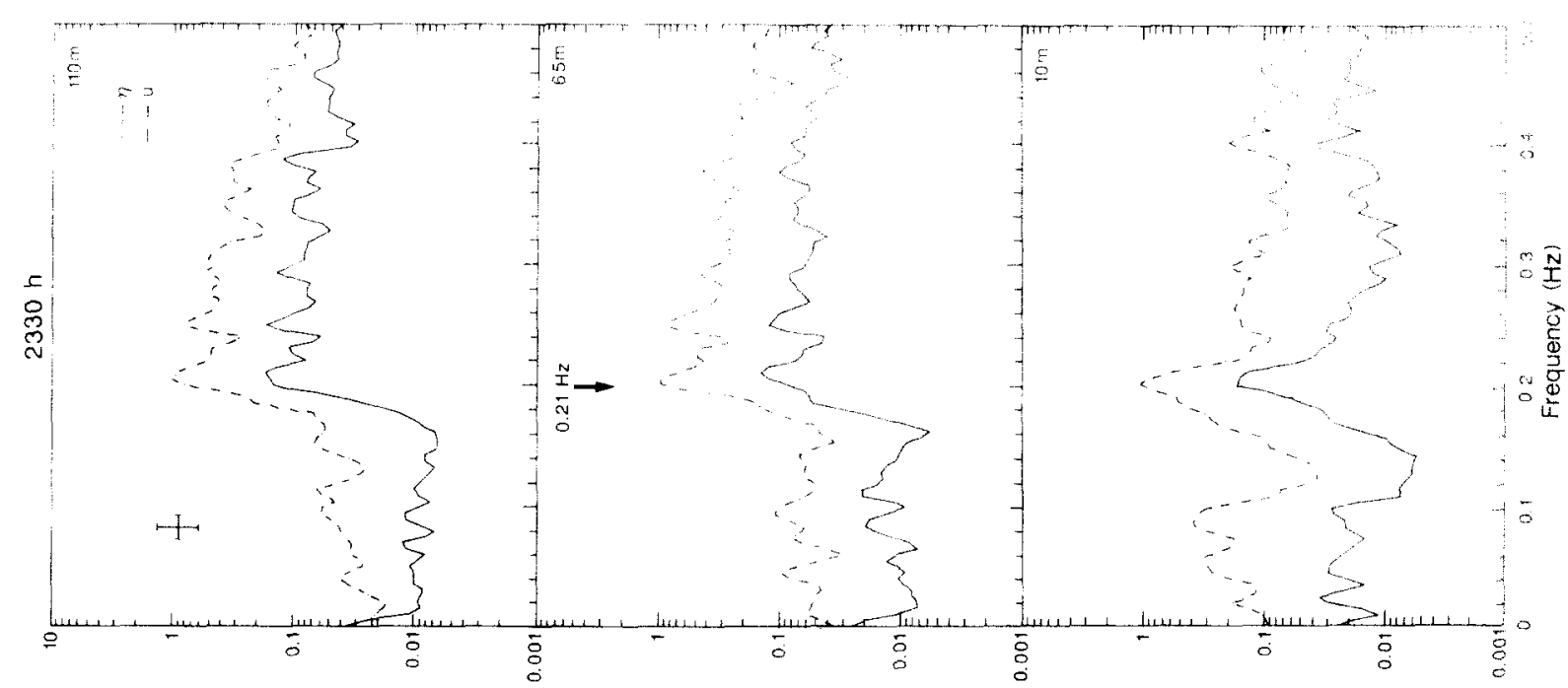

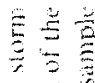

些要

들

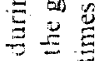

$\because ّ$

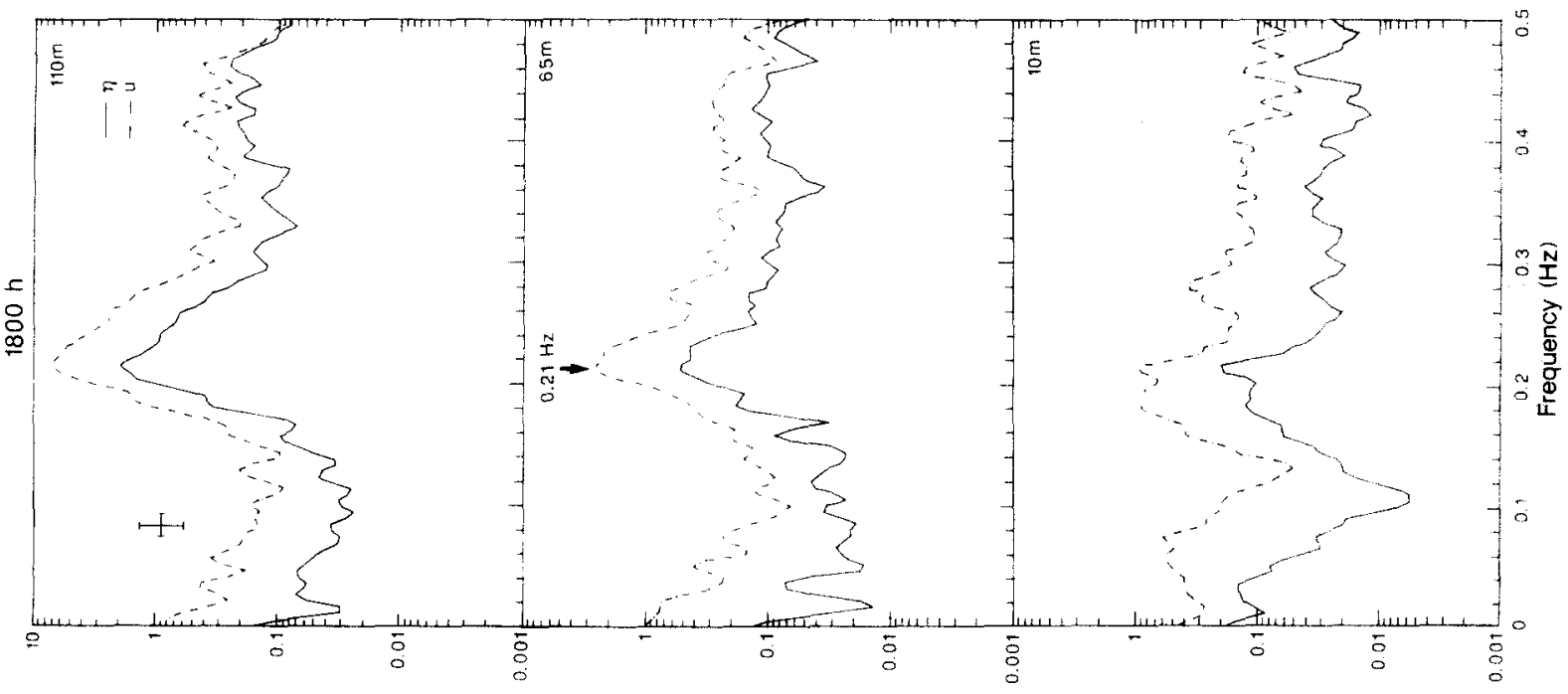

我

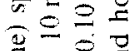

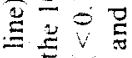

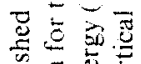

政焉

늘

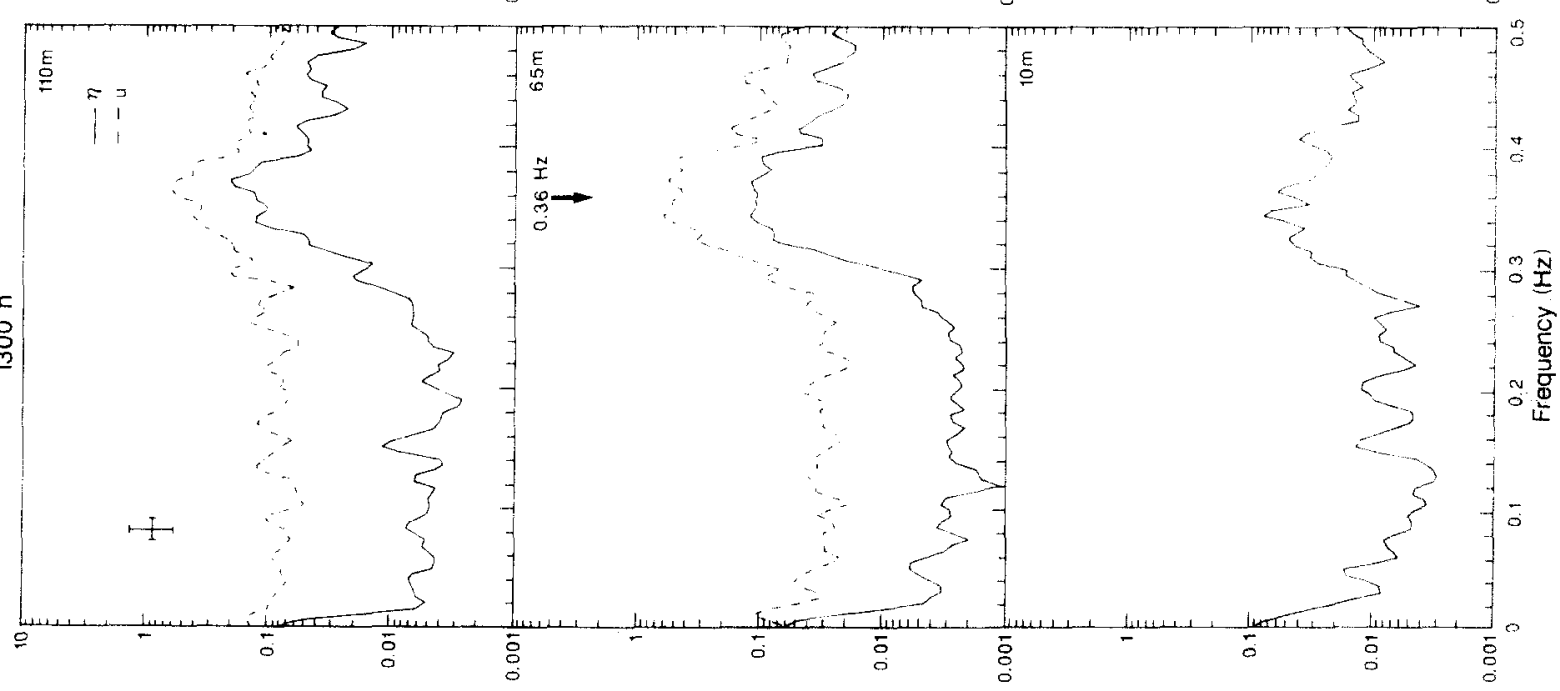

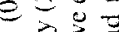

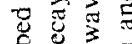


primary parameter used in theoretical models for both sediment transport and beach equilibrium.

As near-bed shear stresses exceeded the threshold for motion of the local sand throughout the storm, the velocity asymmetries observed could potentially induce opposing net sediment transport. The mean flow represents a quasi-steady motion superimposed on the wave-induced oscillation, which could move sediment offshore. In contrast, the wave-induced positive skewness could cause an opposing onshore directed transport, depending upon the degree to which it reflects higher velocities (and/or greater frequency of higher velocities) in the landward direction. Since transport rate is related to some higher power of velocity (Inman and Bagnold, 1963; Wells, 1967; Bowen, 1980a; Bailard, 1981, etc.) it is possible that a few landward directed flows of large magnitude could induce the equivalent transport to many more, but opposing, flows of smaller magnitude, especially if threshold constraints are considered. To produce a net change in elevation of the bottom boundary and hence slope and form changes, however, it is also necessary that spatial gradients in the net sediment flux (or in the forcing functions) occur in order to satisfy mass conservation principles. A more detailed examination of the temporal and spatial variability of both velocity asymmetries and the distribution of onshore and offshore velocity vectors is in order.

Cross-shore sediment transport potential: outer bar

An initial approximation to the net sediment transport potential in the shore-normal direction throughout the storm peak can be obtained by considering cumulative distributions of the positive (onshore-directed) and negative (offshore-directed) velocity vectors. Figure 12 illustrates such distributions for the near-bed flows at the three locations across the landward slope of the outer bar. Early in the storm ( $1300 \mathrm{~h}$, June 16) absolute maximum velocities were all directed onshore, but exceeded the offshore maximum by less than $10 \%$. However, this was the only significant difference and the cross-shore flow fields at each location revealed very similar distributions of onshore and offshore velocity vectors (near identity at $65 \mathrm{~m}$, see Fig. 12).
By $2330 \mathrm{~h}$, again the onshore and offshore velocity fields were similar (near identity at $60 \mathrm{~m}$, see Fig. 12); absolute maxima again varied by less than $10 \%$ and varied between onshore and offshore directed, depending upon the location. The only slight difference that appeared at these times was a greater frequency of offshore flows; this would be an obvious response to the non-linear nature of the shoaling waves. During the storm peak however, the near-bed velocity field was dominated by offshore velocity vectors, and absolute velocity maxima were also directed offshore in association with the mean flows (Fig.12). Furthermore, this offshore net flux of water increased in a lakeward direction from the trough, across the landward slope towards the bar crest (compare areas under the cumulative curve at this time for the 60,65 and $75 \mathrm{~m}$ locations on Fig. 12). It should be noted that continuity of mass was maintained, at least in part. by onshore mean flows and large positive velocity skewness in the upper part of the water column, resulting from both the onshore flux of mass and momentum under waves and the onshore-directed wind stress (see Greenwood and Osborne, 1990).

Although it is impossible to compute sediment transports directly from the velocity vector, it is apparent that, except for the storm maximum, the cumulative distributions were virtually identical; integration results in nearly equal values. Assuming no sediment resistance, these results would indicate little or no net sediment transport in the shore-normal direction. During the storm peak, however, the sediment transport reflected in the near-bed currents would have been affected by the asymmetries present. It might therefore be expected that sediment flux would have been offshore and that the increasing flux of water lakeward across the landward slope would have induced erosion of the local surface. This clearly did not occur in any measureable amount.

Cross-shore sediment transport potential: inner bar

While data are limited to the inner trough, it is evident that during the peak of the storm sediment could be driven offshore by the mean flow and onshore by the positive skewness of the velocity field. During the long post-peak period, however, 


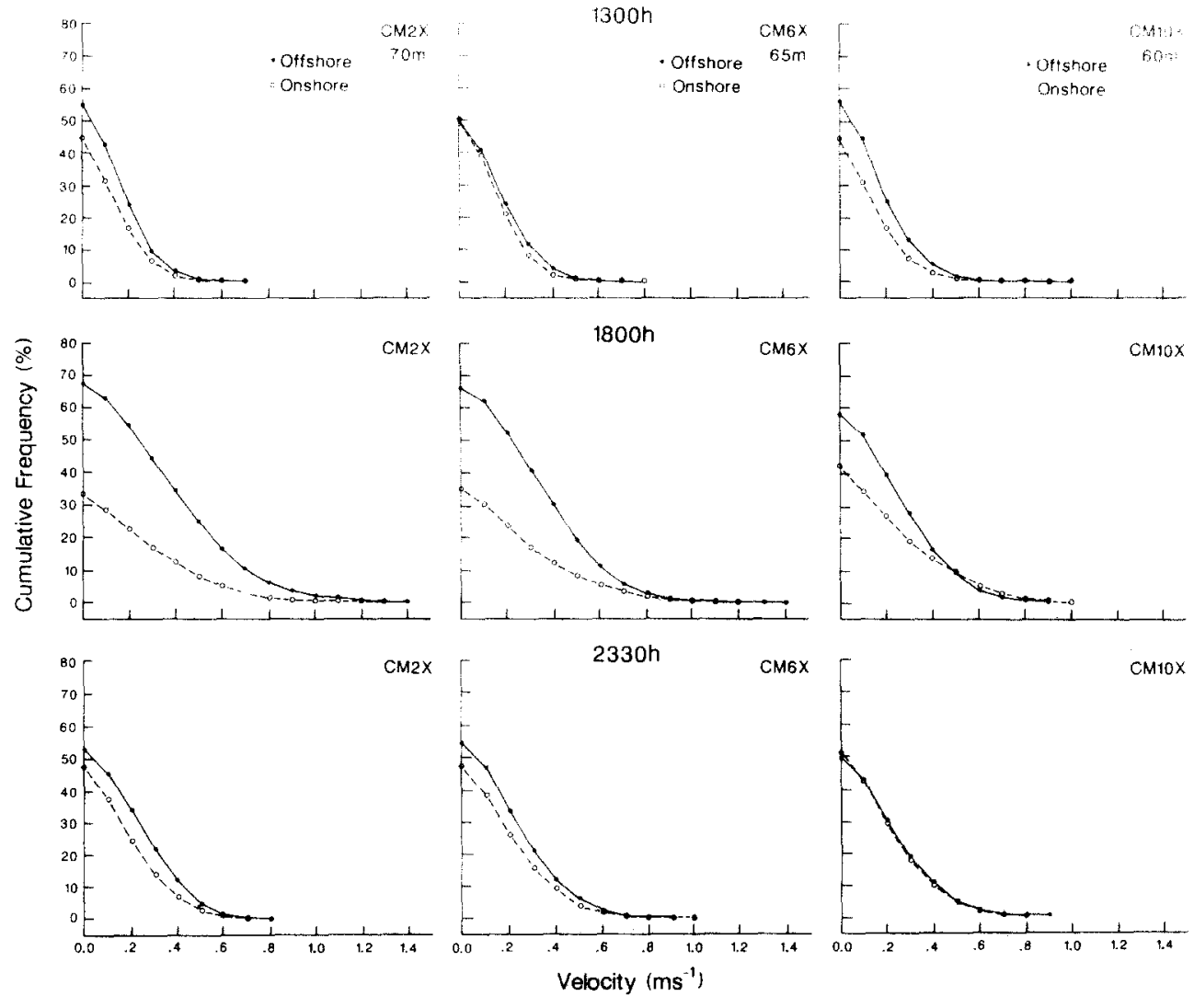

Fig.12. Cumulative frequency distributions of the onshore and offshore velocity vectors at the $0.10 \mathrm{~m}$ elevation across the landward slope of the outer bar (at 60,65 and $70 \mathrm{~m}$ ) at different times through the peak of the storm cycle. Percentages less than $0.01 \%$ (three values in 2925) were eliminated to exclude spurious values.

the most likely direction of transport would be landward under the influence of the large and persistent positive velocity skewness values.

\section{Discussion and conclusions}

Measurements of sediment reactivation, timeintegrated sediment fluxes and bed elevation change using depth-of-activity rods show that a barred upper shoreface in the Canadian Great Lakes consists of a sediment prism in a volumetric "steady state" over a single storm cycle. Morphologically the inner and outer bars at Wymbolwood Beach responded differently to the storm of June 16-18, 1986, and this was associated with differences in the local, near-bed $(0.1 \mathrm{~m})$ velocity fields.

In the inner bar system a large positive (onshore) skewness persisted in the velocity field throughout the 2-day storm and was coupled to a large offshore mean flow (up to $0.20 \mathrm{~m} \mathrm{~s}^{-1}$ ) only for the period of the storm peak $(8 \mathrm{~h})$. Thus, there may have been opposing (even balancing) sediment transports for the storm peak, followed by solely onshore transports during the long decay phase. Certainly the onshore migration of the bar form along the instrument transect on June 17, suggests just such a pattern of sediment flux.

In contrast, the linear outer bar did not migrate but exhibited local slopes in a "steady state" in the short term (single to several storm cycles). This stability was maintained in the presence of extensive sediment transport (averaging $0.14 \mathrm{~m}^{3} \mathrm{~m}^{-2}$ ) induced by currents well above the threshold for sediment motion. However, asymmetries in the near-bed velocity field (mean and skewness) were close to zero across both the landward and 
lakeward slopes of this bar for much of the storm, even under spilling breakers; thus sediment could have simply oscillated in place, giving rise to an "oscillating equilibrium" (Greenwood and Mittler, 1984). A significant question, however, concerns the role of the large offshore mean flow and the large onshore velocity skewness observed over the outer bar during the intense transport conditions of the storm peak. Time integration of the nearbed cross-shore velocity vector at this time across the landward slope indicated a large net offshore flux of water. There was, however, no evidence for an associated net transport of sediment offshore. either erosion of the landward slope or accretion on the bar crest or lakeward slope. Existing sediment transport models based upon simple cross-products of mean properties of the velocity and sediment concentration fields (e.g., Heidegaard and Deigaard, 1988) are therefore inadequate to explain these observations.

With the advent of electro-optical and electroacoustical sensors (e.g., Downing et al., 1981; Hanes, 1988; Hanes et al., 1988; Greenwood et al., 1990), high-resolution measurement of sediment concentrations has revealed the episodic nature of sediment transport and the importance of intermittent suspension in the nearshore zone. Sediment flux is also not related in a simple way to the incident-wave induced velocity field, but is a response to incident waves, wave groups, oscillations in the infragravity wave band, and quasisteady mean flows. Hanes and Huntley (1986), Doering and Bowen (1989) and Osborne et al., (1990) show that substantial onshore transports are associated with the peak wind wave frequency, while smaller offshore transports are dominated by low-frequency motions, including quasi-steady mean flows. Beach and Sternberg (1988) report that suspension transport can be dominated by infragravity motions and that net fluxes are offshore under these conditions. An oscillation at $0.034 \mathrm{~Hz}(\sim 30 \mathrm{~s})$ was identifiable at times across the barred nearshore slope and could have contributed to net sediment transport. Its size and character would indicate, however, that a persistent, well-defined infragravity oscillation at a single frequency was not a major transport mechanism over the outer bar during this storm. Infragravity waves may have played a role in the migration of the inner bar and the development of a threedimensional sinuous form over the storm cycle. Nevertheless, the forcing for sediment transport in this area was provided by incident wave asymmetries and a superimposed steady flow driven by wind- and wave-driven setup.

Recent measurements also show that suspension transport has a dependency at very short time scales (Hanes and Huntley, 1986; Hanes et al., 1988; Greenwood et al., 1990). Since there is a finite time necessary for sediment to rise above the bed into suspension after the initiation of motion, a phase shift between the forcing function and maximum concentration will occur with elevation. A further complication is the generation and shedding of separation vortices in the presence of bedforms and the phase relationships with the wave-induced flows (e.g., Inman and Bowen, 1963; Sleath. 1984). Sediment flux at any point above the bed is therefore a complex time-varying process. which may induce stratification in sediment transport such that a sediment balance could be achieved by reversals within the bottom boundary layer itself. Jaffe et al. (1985) showed that even in the presence of strong offshore mean flows this time dependency induced onshore net transport under the wind waves. The use of simple velocity time series as surrogates for sediment flux (even suspension) on the assumption of sediment motion proportional to and in phase with the velocity field therefore seems erroneous.

Finally, it must be emphasized that the lowest velocity measurement at Wymbolwood Beach was at $0.10 \mathrm{~m}$. Considerable uncertainty therefore exists as to the motions of fluid and sediment below this level. Furthermore, the velocity structure gives no firm evidence whatsoever for either the rate or direction of bedload transport, although the sediment balance over the outer bar might well have been achieved by transport in this layer. Certainly the structural signatures of bedload transport from the landward slope of the outer bar indicated an onshore sediment flux during at least the megaripple and ripple bed phases. It is possible, therefore, as suggested by Bowen (1980a), Chappell (1981) and Leont'ev 
(1985), that the equilibrium slopes of the outer bar could have been achieved by an onshore flux of bedload (bedform migration) balancing an offshore flux of sediment in suspension driven by either the mean flow or the time-varying instantaneous velocities. Only direct measurements of the actual transports taking place, including those close to and at the bed, coupled with morphological measurements will resolve these issues. Furthermore, since the outer bar form did not develop significantly during the experiments described above it remains to be determined what the local fluid dynamics could have been to produce this bar in the first place.

\section{Acknowledgements}

This research was supported by operating and equipment grants from the Natural Sciences and Engineering Research Council Canada to B.G. An Ontario Graduate Scholarship is acknowledged by P.D.O. We would like to thank Drs. D.J. Sherman and B.O. Bauer and R. Blair and A. Hincenbergs for their invaluable assistance in the field. The academic workshops at Scarborough Campus provided the technical support, without which this project would not have been possible. Bill and Margery Palmer are to be thanked for ensuring our sanity while in the field. Finally the senior author acknowledges hospitality and facilities afforded him by Professor John Norrman, Dr. Gunnar Nilsson and B. Gretener (Naturgeografiska Institutionen, Uppsala Universitet) during the final analysis and writing of this manuscript.

\section{References}

Aagaard, T., 1988a. A study on nearshore bar dynamics in a low-energy environment; Northern Zealand, Denmark. J. Coastal Res., 4: 115-128.

Aagaard, T., 1988b. Rhythmic beach and nearshore topography: Examples from Denmark. Geogr. Tidsskr., 88: 55-60.

Aagaard, T., 1988c. Nearshore bar morphology on the lowenergy coast of Northern Zealand, Denmark. Geogr. Ann., 70A: $59-67$.

Allen, P.A., 1985. Hummocky cross-stratification is not produced purely under progressive gravity waves. Nature, 313: $562-564$.

Aubrey, D.G. and Trowbridge, J.H., 1985. Kinematic and dynamic estimates from electromagnetic current meter data. J. Geophys. Res., 90: 9137-9146.
Aubrey, D.G. and Trowbridge. J.H. 1988. Repls. Creophys Res., 93: 1344- 1346.

Aubrey, D.G., Spencer, W.D and Trowbridge. H. 984 Dynamic response of electromagnetic current meters. Woods Hole Oceanogr. Inst. Tech. Rep. WHOI-84-20, $150 \mathrm{pp}$

Bagnold, R.A., 1963. Mechanies of marine sedimentation. In M.N. Hill (Editor), The Sea, Vol. 3. Wiley-Interscience, New York, pp.507-528.

Bagnold, R.A.. 1966. An approach to the sediment transport problem from general physics. U.S. Geol. Surv. Prof. Pap 422-1: $37 \mathrm{pp}$

Bailard, J.A., 1981. An energetics model for a plane sloping beach. J. Geophys. Res., 86: 10938-954.

Bailard, J.A.. 1983. Modeling on-offshore sediment transport in the surf zone. Proc. Coastal Eng. Conf., 18th ASCE. New York, pp.1419-1438

Bailard, J.A.. 1987. Surf zone wave velocity moments. In: R.A Dalrymple (Editor), Coastal Hydrodynamics. ASCE, New York, pp.328--342.

Bailard, J.A and Inman, D.L., 1981. An energetics bedload model for a plane sloping beach: local transport. 1. Geophys. Res., 86: 2035-2043.

Basco, D.R., 1982. Surf Zone Currents, Vol. I. U.S. Army Corps Eng., Coastal Eng. Res. Cent., Misc. Rep. 82-7(I), $243 \mathrm{pp}$.

Bauer, B.O. and Greenwood, B., 1990. Modification of a linear bar-trough system by a standing edge wave. Mar. Geol., 92 177-204.

Beach, R.A. and Sternberg, R.W., 1988. Suspended sediment transport in the surf zone: response to cross-shore infragravity motion. Mar. Geol., 80: 61-79.

Bowen, A.J., 1980a. Simple model of nearshore sedimentation: beach profiles and longshore bars. In: S.B. McCann (Editor) The Coastline of Canada. Geol. Surv. Can., Pap. 80-10:1-11.

Bowen, A.J., 1980b. Nearshore velocity measurements and beach equilibrium. Proc. Can. Coastal Conf. (Burlington). Natl. Res. Counc. Can., Assoc. Comm. Res. Coastal Erosion and Sedimentation, Ottawa, Ont., pp.21-30.

Bowen, A.J. and Doering, J.C., 1985. Nearshore sediment transport: estimates from detailed measurements of the nearshore velocity field. Proc. Coastal Eng. Conf., 19th ASCE, New York, pp. 1703-1714

Bowen, A.J. and Huntley, D.A., 1984. Waves, long waves and nearshore morphology. In: B. Greenwood and R.A. Davis Jr. (Editors), Hydrodynamics and Sedimentation in Wavedominated Coastal Environments. Mar. Geol., 60: 1-14.

Bowen, A.J. and Inman, D.L., 1971. Edge waves and crescentic bars. J. Geophys. Res., 76: 8862-8871.

Bowman, D. and Goldsmith, V., 1983. Bar morphology of dissipative beaches: an empirical model. Mar. Geol., 51 15-33.

Bowman, D., Arad, A., Rosen, D.S., Kit, E., Goldberg, R. and Slavicz, A., 1988a. Flow characteristics along the rip current system under low energy conditions. Mar. Geol., 82 149-167.

Bowman, D., Rosen, D.S., Kit, E., Arad, A. and Slavicz, A., 1988b. Flow characteristics at the rip current neck under low energy conditions. Mar. Geol., 79: 41-54.

Brander, R.W., 1988. A synthetic wave climatology of 
Nottawasaga Bay, Ontario. B.Sc. Dissert., Univ. Toronto, Ont., 117 pp. (Unpubi.).

Carter, R.W.G., 1978. Small scale transverse bars in Lough Neagh, Northern Ireland. J. Earth Sci., R. Dublin Soc., 1: 205-209.

Carter, T.G., Liu, P.L. and Mei, C.C., 1973. Mass transport by waves and offshore sand bedforms. J. Waterways, Harbors Coastal Eng. Div., ASCE, 99: 165-184.

Chappell, J., 1981. Inshore-nearshore morphodynamics -- a predictive model. Proc. Coastal Eng. Conf, 17th. ASCE, New York, pp.963-977.

Chappell, J. and Wright, L.D., 1979. Surf zone resonance and coupled morphology. Proc. Coastal Eng. Conf, 16th. ASCE, New York, pp.1359-1377.

Cook, D.O., 1970. Models for nearshore sand transport. Proc. Conf. Great Lakes Research, 13th (Univ. Buffalo, N.Y.), pp. $210-216$.

Cowell, P.J., 1982. Breaker stages and surf structure on beaches. Coastal Stud. Unit, Univ. Sydney, Tech. Rep. 82/7.

Cunningham, P.M., Guza, R.T. and Lowe, R.L., 1979. Dynamic calibration of electromagnetic flowmeters. Proc. Oceans '79. IEEE, New York, pp.298-301.

Dally, W.R. and Dean, R.G., 1984. Suspended sediment transport and beach profile evolution. J. Waterways, Ports, Coastal Ocean Eng., ASCE, 111: 15-33.

Davidson-Arnott, R.G.D and Greenwood, B., 1974. Bedforms and structures associated with bar topography in the shallowwater wave environment, Kouchibouguac Bay, New Brunswick, Canada. J. Sediment. Petrol., 44: 698-704.

Davidson-Arnott, R.G.D. and Greenwood, B., 1976. Facies relationships on a barred coast, Kouchibouguac Bay, New Brunswick, Canada. In: R.A. Davis, Jr. and R.L. Ethington (Editors). Beach and Nearshore Sedimentation. Soc. Econ. Paleontol. Mineral. Spec. Publ., 24: 149-168.

Davidson-Arnott, R.G.D. and McDonald, R.A., 1989. Nearshore water motion and mean flows in a multiple parallel bar system. Mar. Geol., 86: 321-338.

Davidson-Arnott, R.G.D. and Pember, G., 1980. Morphology and sedimentology of multiple bar systems, Southern Georgian Bay, Ontario. In: S.B. McCann (Editor), The Coastline of Canada. Geol. Surv. Can. Pap., 80-10: 417-428.

Deigaard, R., Fredsoe, J. and Hedegaard, I.B., 1986. Mathematical model for littoral drift. J. Waterways, Ports, Coastal Ocean Eng., ASCE, 112: 351-369.

De Zeeuw, C., 1980. Instructions and standards manual for the National Water Research Institute Towing Carriage Facility. Tech. Serv. Sect., Hydraul. Div., Natl. Water Res. Inst., $70 \mathrm{pp}$.

Dhyr-Nielsen, M. and Sorensen, T., 1970. Some sand transport phenomena on coasts with bars. Proc. Coastal Eng. Conf., 12th. ASCE, New York, pp.855-866.

Dingler, J.R. and Inman, D.L., 1977. Wave-formed ripples in nearshore sands. Proc. Coastal Eng. Conf., 15th. ASCE. New York, pp.2109-2126

Dixon, W.J., 1971. BMD: Biomedical Computer Programs. Univ. California Press, Berkeley, Calif., $600 \mathrm{pp}$.

Dixon, W.J. and Brown, M.B., 1979. BMD P-79: Biomedical Computer Programs, P-Series. Univ. California Press, Berkeley, Calif.

Doering, J.C.. 1988. Wave-wave interactions in the nearshore.
Ph.D. Dissert., Dalhousie Univ., Halifax, N.S., 139 pp. (Unpubl.).

Doering, J.C. and Bowen. A.J., 1985. Skewness et al., the spatial distribution of some moments of the nearshore velocity field. Proc. Can. Coastal Conf. (St. John’s). Natl. Res. Counc. Can., Assoc. Comm. Res. Coastal Erosion and Sedimentation, Ottawa, Ont., pp.5-16.

Doering, J.C. and Bowen, A.J.. 1987a. Skewness in the nearshore zone: a comparison of estimates from MarshMcBirney current meters and colocated pressure sensors. J. Geophys. Res., 93: 13173-13188.

Doering, J.C. and Bowen, A.J., 1987b. Vertical variation of wave-induced flows? Proc. Can. Coastal Conf. (St. John's). Nat. Res. Counc. Can., Assoc. Comm. Res. Coastal Erosion and Sedimentation, Ottawa, Ont., pp.227-238.

Doering, J.C. and Bowen, A.J., 1989. Wave-induced flow and nearshore suspended sediment. Proc. Coastal Eng. Conf., 21st. ASCE, New York, pp.1452-1463.

Downing, J.P., Sternberg, R.W. and Lister, C.R.B.. 1981. New instrumentation for the investigation of sediment suspension processes in the shallow marine environment. In: C.A. Nittrouer (Editor), Sedimentary Dynamics of Continental Shelves. Mar. Geol., 42: 19-34.

Exon. N.F., 1975. An extensive offshore sand bar field in the western Baltic Sea. Mar. Geol., 18: 197-212.

Goldsmith, V., Bowman, D. and Kiley, K., 1982. Sequential stage development of crescentic bars: Hahoterim Beach. Southeastern Mediterranean. J. Sediment. Petrol., 52: 233-249

Greenwood, B., 1982. Bars. In: M.L. Schwartz (Editor), Encyclopaedia of Beaches and Coastal Environments. Dowden, Hutchinson and Ross, Stroudsburg, Pa., pp.135-139.

Greenwood, B., 1987. Sediment balance and bar morphodynamics in a multiple bar system, Georgian Bay, Canada. In: V. Gardiner (Editor), International Geomorphology, Part 1 Wiley, Chichester, pp.1119-1143.

Greenwood, B. and Davidson-Arnott, R.G.D.. 1975. Marine bars and nearshore sedimentary processes, Kouchibouguac Bay, New Brunswick, Canada. In: J. Hails and A. Carr (Editors), Nearshore Sediment Dynamics and Sedimentation. Wiley, London, pp.123-150.

Greenwood, B. and Davidson-Arnott, R.G.D., 1979. Sedimentation and equilibrium in wave-formed bars: a review and case study. Can. J. Earth Sci., 16: 312-332.

Greenwood, B. and Hale, P.B., 1980. Depth of activity, sediment flux, and morphological change in a barred nearshore environment. In: S.B. McCann (Editor), The Coastline of Canada. Geol. Surv. Can. Pap., 80-10: 89-109.

Greenwood, B. and Hale, P.B., 1982. Lagrangian sediment motion in a crescentic nearshore bar under storm-induced waves and currents. Can. J. Earth Sci., 19: 424-433.

Greenwood, B. and Mittler, P.R., 1984. Sediment flux and equilibrium slopes in a barred nearshore. In: B. Greenwood and R.A. Davis, Jr. (Editors), Hydrodynamics and Sedimentation in Wave-dominated Coastal Environments. Mar. Geol., 60: 79-98.

Greenwood, B. and Osborne, P.D., 1990. Vertical and horizontal structure in cross-shore flows: an example of undertow and wave set-up on a barred beach. Coastal Eng. in press. 
Greenwood, B. and Sherman, D.J., 1983. Shore-parallel flows in a barred surf zone. Proc. Coastal Eng. Conf.. 18th ASCE, New York, pp. 1677-1696.

Greenwood, B. and Sherman, D.J., 1984. Waves, currents. sediment flux and morphological response in a barred nearshore system. In: B. Greenwood and R.A. Davis Jr. (Editors), Hydrodynamics and Sedimentation in WaveDominated Coastal Environments. Mar. Geol, 60: 31 - 61

Greenwood, B. and Sherman, D.J., 1986a. Longshore current profiles and lateral mixing across the surf zone of a barred nearshore. Coastal Eng., 10: 149-168.

Greenwood, B. and Sherman, D.J. 1986b. Hummocky crossstratification in the surf zone: flow parameters and bedding genesis. Sedimentology, 33: 33-45.

Greenwood. B. and Sherman, D.J., 1987. Bedforms and bed roughness in prototype surf zones. In: Proc. Workshop Roughness and Friction. Natl. Res. Counc. Can., Assoc. Comm. Shorelines, Ottawa, Ont., pp.79-91.

Greenwood, B., Hale, P.B. and Mittler, P.R., 1980. Sediment flux determination in the nearshore zone: prototype measurements. In: Workshop Instrumentation for Currents and Sediments in the Nearshore Zone. Natl. Res. Counc. Can., Assoc, Comm. Res. Shoreline Erosion and Sedimentation. Ottawa, Ont., pp.99-120.

Greenwood, B., Davidson-Arnot1, R.G.D., Hale, P.B. and Mittler, P.R., 1984. A Klovan-type box corer for use with SCUBA. Geo-Mar. Lett., 4: 59-62

Greenwood, B., Dingler, J.R., Sherman, D.J., Anima, R.J. and Bauer. B., 1985. Monitoring bedforms under waves using high resolution remote tracking sonars (HRRTS). Proc. Can. Coastal Conf. (St. John's). Natl. Res. Counc. Can., Assoc. Comm. Res. Shoreline Erosion and Sedimentation, Ottawa, Ont., pp. 143-158.

Greenwood, B., Osborne, P.D., Bowen, A.J., Hazen, D.G. and Hay, A.E., 1990. C-COAST: The Canadian Coastal Sediment Transport Programme -.. suspended sediment transport under waves and currents. Proc. Can. Coastal Conf. (Kingston). Natl. Res. Counc. Can., Assoc. Comm. Shorelines, pp.319-336.

Guza, R.T., 1988. Comment on "Kinematic and dynamic estimates from electromagnetic current meter data" by D.G. Aubrey and J.H. Trowbridge. J. Geophys. Res., 93: $1337-1343$.

Guza, R.T. and Thornton, E.B., 1985. Velocity moments in nearshore. J. Waterways, Ports, Coastal Ocean Eng. Div., ASCE., 111: 235-256.

Guza, R.T., Clifton, M.C. and Rezvani, F., 1988. Field intercomparisons of electromagnetic current meters. J. Geophys. Res., 93: 9302-9314.

Hale, P.B. and Greenwood, B., 1980. Storm wave climatology: a study of the magnitude and frequency of geomorphic process. In: S.B. McCann (Editor), The Coastline of Canada. Geol. Surv. Can. Pap., 80-10: 70-88.

Hamblin, P.F., Marmoush, Y.M.R., Boyce, F.M. and Smith, A.A., 1987. Field evaluation of an electromagnetic current meter based vertical profiler. J. Geophys. Res., 92: $11867-11872$.

Hands, E.B., 1976. Observations of barred coastal profiles under the influence of rising water levels, Eastern Lake Michigan, 1967-71. U.S. Army Corps Eng., Coastal Eng. Res. Cent., Tech. Rep. 76-1, 113 pp.
Hanes, D.M.. 1988. Intermittent sediment suspenswon and fes implications to sand tracer dispersal in was fommated environments. Mar. Geol., 81: 175 183.

Hanes, D.M. and Huntley, D.A., 1986. Continuous measurements of suspended sand concentration in a wave dominated nearshore environment. Cont. Shelf Res., 6: 585.596.

Hanes, D.M., Vincent, C.E., Huntley, D.A. and Clarke. T. . $_{\text {. }}$ 1988. Acoustic measurements of suspended sand concentration in the $\mathrm{C}^{2} \mathrm{~S}^{2}$ experiment at Stanhope Lane, Prince Edward Island. Mar. Geol., 81: $185-196$.

Hardisty, J., 1985. A note on negative beach slopes and flow asymmetry. Mar. Geol., 69: 203 206.

Heidegaard, I.B. and Deigaard, R., 1988. A model for crossshore sediment transport and coastal profile development. Proc. Int. Symp. Wave Res. and Coastal Eng. 2nd (Hanover).

Holman. R.A and Bowen, A.J., 1982. Bars, bumps and holes: models for the generation of complex beach topography. J Geophys. Res., 87: 457-468.

Hunter, R.E., Clifton, H.E. and Phillips, R.L., 1979. Depositional processes, sedimentary structures and predicted vertical sequences in barred nearshore systems. J. Sediment. Petrol., 49: $711 \cdots 726$.

Huntley, D.A., 1980. Edge waves in a crescentic bar system. In: S.B. McCann (Editor), The Coastline of Canada. Geol. Surv. Can, Pap., 80-10: 111-112.

Inman, D.L. and Bagnold, R.A., 1963. Littoral processes. In M.N. Hill (Editor). The Sea. Wiley-Interscience, New York. pp.529-533.

Inman, D.L. and Bowen, A.J., 1963. Flume experiments on sand transport by waves and currents. Proc. Coastal Eng. Conf,, 8th ASCE, New York, pp.137-150.

Inman, D.L. and Frautschy, J.D., 1966. Littoral processes and the development of shorelines. Proc. Coastal Eng. Spec. Conf. (Santa Barbara, Calif.). ASCE, New York, pp.511-536.

Jaffe, B.E., Sternberg, R.W. and Sallenger, A.H., 1985: The role of suspended sediment in shore-normal beach profile changes. Proc. Coastal Eng. Conf., 19th. ASCE, New York, pp. 1983-1996

Jago, C.F. and Hardisty, J., 1984. Sedimentology and morphodynamics of a macro-tidal beach, Pendine Sands, sW Wales. In: B. Greenwood and R.A. Davis, Jr. (Editors), Hydrodynamics and Sedimentation in Wave-Dominated Coastal Environments. Mar. Geol., 60: 123-154.

Katoh, K., 1984. Multiple longshore bars formed by long period standing waves. Rep. Port Harbour Res. Inst., 23: $3-46$.

Kim, C.S. and Wright, L.D., 1987. Longshore bars and mass transport induced by long waves. In: R.A. Dairymple (Editor), Coastal Hydrodynamics. ASCE, New York, pp. 564-578.

Kobayashi, N., 1988. Review of wave transformation and cross-shore sediment transport processes in surf zones. J. Coastal Res., 4: 435-445.

Komar, P.D., 1978. Relative quantities of suspension versus bed-load transport on beaches. J. Sediment. Petrol., 48 921-932.

Larsen, L.H., 1982. A new mechanism for seaward dispersion of mid-shelf sediments. Sedimentology, 29: 279-284.

Leont'ev, I.O., 1985. Sediment transport and beach equilibrium profile. Coastal Eng., 9: 277-291. 
Longuet-Higgins, M.S., 1953. Mass transport in water waves. Philos. Trans. R. Soc. London, Ser, A, 245: 535-581.

Longuet-Higgins, M.S., 1972. Recent progress in the study of longshore currents. In: R.E. Meyer (Editor), Waves on Beaches and Resulting Sediment Transport. Academic Press, New York, pp.203-248.

Longuet-Higgins, M.S., 1981. The unsolved problem of breaking waves. Proc. Coastal Eng. Conf., 14th ASCE, New York, pp.1-28.

Longuet-Higgins, M.S., 1983. Wave set-up, percolation and undertow in the surf zone. Proc. R. Soc. London, Ser. A, 390: 283291.

Longuet-Higgins, M.S. and Stewart, R.W., 1964. Radiation stress in water waves; a physical discussion with applications. Deep-Sea Res., 11: 529-562.

Osborne, P.D., Greenwood, B. and Bowen, A.J., 1990. Crossshore suspended sediment transport on a non-barred beach: the role of wind waves, infragravity waves and mean flows. Proc. Can. Coastal Conf. (Kingston). Natl. Res. Counc. Can., Assoc. Comm. Shorelines, pp.349-361.

Roelvink, J.A. and Stive, M.J.F., 1989. Bar-generating crossshore flow mechanisms on a beach. J. Geophys. Res., 94: 4785-4800.

Sallenger, A.H. and Holman, R.A., 1987. Infragravity waves over a natural barred profile. J. Geophys. Res., 92: 9531-9540.

Sallenger. A.H., Holman, R.A. and Birkemeier, W.A., 1985. Storm-induced response of a nearshore bar system. Mar. Geol., 64: 237-257.

Seymour. R.J. and Castel, D., 1989. Validation of cross-shore transport formulations. Proc. Coastal Eng. Conf., 21st. ASCE. New York, pp.1676-1688.

Seymour, R.J. and King, D.B., 1982. Field comparisons of cross-shore transport models. J. Waterway, Port, Coastal Ocean Eng. Div., ASCE, 108: 163-179.

Shepard, F.P., Emery, K.O. and LaFond, E.C., 1941. Rip currents: a process of geological importance. J. Geol., 49: 337-369.

Sherman, D.J. and Greenwood, B., 1984. Boundary roughness and bedforms in the surf zone. In: B. Greenwood and R.A. Davis Jr. (Editors), Hydrodynamics and Sedimentation in Wave-Dominated Coastal Environments. Mar. Geol., 60: 199-218.

Shi, N.C. and Larsen, L.H., 1984. Reverse sediment transport induced by amplitude modulated waves. Mar. Geol., 54: 181-200

Short, A.D., 1978. Wave power and beach stages -- a global model. Proc. Coastal Eng. Conf., 16th. ASCE, New York, pp. $1145-1162$.

Short, A.D., 1979. Three-dimensional beach stage model. J. Geol., 87: 553-571.

Short, A.D., 1984. Beach and nearshore facies: southeast Australia. In: B. Greenwood and R.A. Davis Jr. (Editors), Hydrodynamics and Sedimentation in Wave-Dominated Coastal Environments. Mar. Geol., 60: 261-282.

Short, A.D., 1985. Rip current type, spacing and persistence, Narrabeen Beach, Australia. Mar. Geol., 65: 47-71.

Sleath, J.F.A., 1984. Sea Bed Mechanics. Wiley-Interscience, New York, 335 pp.
Sonu, C.J., 1972. Field observations of nearshore and meandering currents. J. Geophys. Res., 77: 3232-3247.

Sternberg, R.W., Shi, N.C. and Downing, J.P. 1989. Continuous measurements of suspended sediment. In: R.J. Seymour (Editor), Nearshore Sediment Transport. Plenum, New York. pp.231-258.

Stive, M.J.F., 1986. A model for cross-shore sediment transport. Proc. Coastal Eng. Conf., 20th. ASCE. New York. pp. $1550-1564$.

Stive, M.J.F. and Battjes, J.A.. 1984. A model for offshore sediment transport. Proc. Coastal Eng. Conf, 19th. ASCE, New York, pp.1145-1162.

Stive, M.J.F. and Wind, H.G., 1986. Cross-shore mean flow in the surf zone. Coastal Eng.. 10:325-340.

Sunamura, T., 1988. Beach morphologies and their change. In: K. Horikawa (Editor), Nearshore Dynamics and Coastal Processes. Univ. Tokyo Press, Tokyo, pp.136 166.

Sunamura, T. and Takeda, I., 1984. Landward migration of inner bars. In: B. Greenwood and R.A. Davis Jr. (Editors), Hydrodynamics and Sedimentation in Wave-Dominated Coastal Environments. Mar. Geol., 60: 63--78.

Svendsen, I.A., 1984. Mass flux and undertow in a surf zone. Coastal Eng. 8: 347-365.

Trowbridge, J. and Madsen, O.S., 1984. Turbulent wave boundary layers 2 . Second order theory and mass transport. J. Geophys. Res., 89: 7999-8007.

Truxillo, S.G., 1970. Development of a resistance-wire wave gauge for shallow-water wave and water level investigations. Coastal Stud. Inst., Louisiana State Univ., Baton Rouge, La. (Unpubl.).

Wells, D.R., 1967. Beach equilibrium and second order wave theory. J. Geophys. Res., 72: 497-504.

Wright, L.D. and Short, A.D., 1983. Morphodynamics of beaches and surf zones in Australia. In: P.D. Komar (Editor), CRC Handbook of Coastal Processes and Erosion. CRC Press, Boca Raton, Fla., pp.35-64.

Wright, L.D. and Short, A.D., 1984. Morphodynamic variability of surf zones and beaches: a synthesis. Mar. Geol., 26: 93-118.

Wright, L.D., Chappell, J., Thom, B.G., Bradshaw, M. and Cowell, P., 1979. Morphodynamics of reflective and dissipative beach and inshore systems, southeastern Australia. Mar. Geol., 32: 105-140.

Wright, L.D., Guza, R.T. and Short, A.D., 1982. Dynamics of a high energy dissipative surf zone. Mar. Geol., 45: 41-62.

Wright, L.D., Neilsen, P., Shi, N.C. and List, J.H., 1986. Morphodynamics of a bar-trough surf zone. Mar. Geol., 70: 251-286

Wright, L.D., Short, A.D., Boon, J.D. III, Hayden, B., Kimball, S. and List, J.H., 1987. The morphodynamic effects of incident wave groupiness and tide range on an energetic beach. Mar. Geol., 74: 1-20.

Zampol, J.A. and Inman, D.L., 1989. Discrete measurements of suspended sediment. In: R.J. Seymour (Editor), Nearshore Sediment Transport. Plenum, New York, pp.259-272.

Zenkovitch, V.P., 1967. Processes of Coastal Development. Interscience, New York, 738 pp. 